\title{
COMMENTS
}

\section{THE REPORTER AS CITIZEN: NEWSPAPER ETHICS AND CONSTITUTIONAL VALUES}

\author{
JASON P. ISRALOWITZ†
}

\begin{abstract}
"You're either a member of the public or a member of the press."
- Mayor Mel Hughes explaining his decision to bar a reporter from asking questions at city council meetings.
\end{abstract}

\section{"We're human beings first. and joumalists second; otherwise there's something entirely wrong with us. ${ }^{22}$ \\ - Former New York Times columnist Tom Wicker}

\section{INTRODUCTION}

American journalists, ${ }^{3}$ who toil collectively under the constitutional banner of freedom of the press, ${ }^{4}$ must surrender their individual rights to freedom of expression as a condition of employment at most newspapers. This irony is rooted in the ethic

† B.S. 1990, Boston University; J.D. Candidate 1993, University of Pennsylvania. This Comment was written in conjunction with C. Edwin Baker's Mass Media Policy seminar. I am deeply indebted to Professor Baker for his guidance and the example of his scholarship. Special thanks also to Comment Editor Lani Remick for her keen editing, and to Mike Farber and Doug Halijan for reviewing earlier drafts and offering important suggestions. I dedicate this Comment to my parents, Murray and Harriet Isralowitz, and to my brother, Stuart, who have supported both my journalistic and legal aspirations.

1 Tim Waters, Publisher Regains Right to Speak at City Meetings, L.A. TIMES, July 5, 1990, at B3 (quoting Rancho Palos Verdes Mayor Mel Hughes). This incident is discussed further infra note 93.

${ }^{2}$ ABC World News Tonight with Peter Jennings (ABC television broadcast, Jan. 3, 1992) (transcript available in LEXIS, Nexis Library, Script File) (interview with former New York Times reporter and columnist Tom Wicker).

${ }^{3}$ Since this Comment focuses on the issue of newspaper ethics, the term "journalists" refers principally to reporters employed at newspapers. Many of the examples and arguments contained herein, however, apply to both print and broadcast journalists. I will specify to which of these groups I am referring where the distinction is relevant to the issues at hand. In addition, throughout this Comment the term "the press" or "the media" refers to print and broadcast journalism as a collective institution.

1 "Congress shall make no law ... abridging the freedom of speech, or of the press .... U.S. CONST. amend. I. 
of objectivity, which dictates that reporters present news in a neutral and balanced fashion, free from the influence of their personal opinions. ${ }^{5}$ In pursuit of this ideal, many newspapers require that staff members abstain from participation in political or community affairs in order to preserve the appearance of neutrality. ${ }^{6}$ The Washington Post, for example, prohibits staff members from engaging in advocacy even on issues they do not cover for the paper. ${ }^{7}$

In recent years, such restrictions have led to the dismissal of a number of journalists based on their participation in political demonstrations, local government, and other off-duty activity. ${ }^{8}$ Most of these journalists had been advocating for causes far removed from the issues they were assigned to cover. This separation of individual activism from professional duties would seem to alleviate the possibility of personal political agendas skewing news content. Some newspaper employers, however, have adopted overbroad restrictions on political and social involvement, thus interfering with the private lives of their employees even when content is not implicated.

This Comment argues that absolute prohibitions on off-duty activism unjustifiably infringe upon the individual freedom of media personnel and should therefore be rescinded by employers. In mandating that newsroom employees take vows of political abstinence, newspapers deny journalists a liberty interest ${ }^{9}$ enjoyed $^{\text {. }}$

5 See BEN H. BAgdikian, THE MEdA MONOPOLY 130 (1990) (discussing the rise of objectivity and its effect on news coverage); ROBERT MIRALDI, MUCRRAKING AND OBJECTIVITY: JOURNALISM'S COLLIDING TRADITIONS 6 (1990) (contrasting objective reporting and muckraking).

'See infra note 45 and accompanying text.

7 See Alex S. Jones, Demonstration Renews Question of Conflict for Newspapers, N.Y. TIMES, Apr. 16, 1989, § 1, at 28. The Post requires that newsroom employees "avoid active involvement in any partisan causes-politics, community affairs, social action, demonstrations-that could compromise or seem to compromise our ability to report and edit fairly." See Benjamin C. Bradlee, Standards and Ethics, in THE WASHINGTON POST DESKBOOK ON STYLE 1, 3 (Thomas W. Lippman ed., 2d ed. 1989); see also Richard Harwood, Everybody's Sin But Our Own, WASH. POST, Apr. 16, 1989, at B6 (discussing provisions of the Washington Post's employment manual for newsroom employees); Eleanor Randolph, The Media and the March: The Ethics of Joining the Abortion Protest, WASH. POST, Apr. 15, 1989, at C1 (reporting the reaction of Post editors to the presence of journalists at an abortion-rights demonstration). Among other papers that prohibit all forms of advocacy, irrespective of whether the issue implicates a reporter's beat, are the Philadelphia Inquirer and the Chicago Tribune. See Jones, supra, at 28.

${ }^{8}$ See infra Part II.

${ }^{9}$ Since the First Amendment protects individual freedom from government 
by other citizens: ${ }^{10}$ the freedom to engage in activities that implicate personal development and self-definition. ${ }^{11}$ In addition to abridging the individual liberty of reporters, restrictive codes of ethics may effectively exclude from public discourse the most informed and articulate voices of the citizenry. ${ }^{12}$ These costs demand a compelling justification. Yet limits on outside activity more often rest on the institutional imperative of avoiding the "appearance of impropriety" rather than on legitimate concerns about ensuring objective reporting. The inadequacy of this justification $^{13}$ suggests that newspapers should amend their ethical standards to allow newsroom personnel, at a minimum, to retain their free speech and political participation rights as to outside activity that has no relation to the content of their reporting. Alternatively, several legal remedies may provide an important measure of protection for off-duty activity that remains clearly divorced from editorial content. ${ }^{14}$

The adoption of less restrictive standards on journalistic activism would have broader implications for the institutional functions of the press. Such a move could promote political and sociological diversity among reporters and thereby help to realize a more pluralistic conception of news. A movement away from wholly detached journalism also could also foster a more spirited brand of

infringement only, the actions taken by private newspaper employers do not directly implicate the constitutional rights of journalists. This Comment argues, however, that restrictive codes of ethics infringe the same kind of liberty interest that receives protection from government abridgement via the First Amendment.

${ }^{10}$ The Hatch Act, which bars certain government employees from "tak[ing] an active part in political management or in political campaigns," might be seen as an exception to this statement. See 5 U.S.C. $\$ 7324$ (1988). Yet these restrictions often sweep far more widely than the provisions of the Hatch Act, which preserves the right of a government employee to "express his opinion on political subjects and candidates" and does not reach many types of outside activity such as issue demonstrations and community involvement.

${ }^{11}$ Several First Amendment theorists have identified self-realization as a principal value underlying freedom of expression. See, e.g., C. EDWIN BAKER, HUMAN LIBERTY AND FREEDOM OF SPEECH 254 (1989) (explaining that protecting press professionals' constitutional freedoms "may promote individual liberty by contributing to their selfactualization"); THOMAS I. EMERSON, TOWARD A GENERAL THEORY OF THE FIRST AMENDMENT 4 (1968) (stating that freedom of expression guarantees "individual selffulfillment"); Martin H. Redish, The Value of Free Speech, 130 U. PA. L. REV. 591, 593 (1982) (arguing that freedom of speech serves principally the value of "individual selfrealization").

${ }^{12}$ See John L. Hulteng, Playing It Straight: A Practical Discussion of the ETHICAL PRINCIPLES OF THE AMERICAN SOCIETY OF NEWSPAPER EDTTORS 30 (1981).

${ }^{13}$ See infra notes $126-41$ and accompanying text.

14 See infra Part IV. 
adversarial reporting in the tradition of muckraking journalism. ${ }^{15}$ Endowed with greater autonomy in their work, journalists may more effectively advocate reform on behalf of their audiences and challenge abusers of power. Since this aspect of editorial autonomy cuts to the heart of newspaper content, the special First Amendment status of the press precludes legal intervention designed to promote on-the-job freedom. ${ }^{16}$ This Comment therefore argues that, as a normative matter, newspapers should accord individual journalists greater freedom to explore their identities as citizens, both on and off the job.

Part I of this Comment sketches the historical development of American journalism and the transition from partisanship to objectivity that ultimately led to the promulgation of codes of ethics restricting off-duty conduct. Part II analyzes a number of recent incidents in which journalists were dismissed or reprimanded for resisting employer efforts to limit their outside activity. A review of such incidents reveals that prohibitions on off-duty activity may substantially impair the ability of media personnel to vindicate important First Amendment values.

Part III examines employer rationales for such limitations and finds that they derive from unwarranted assumptions about both the impact of reporters' personal values on media content and the public relations value of codes of ethics. Part IV explores several employment law remedies for journalists who have been discharged for engaging in activism on their own time. In a limited class of cases, these remedies may afford protection for the civil liberties of individual reporters. Part V suggests a more fundamental change in norms, arguing that newspapers should accommodate not only off-duty political and community involvement but also a more honest infusion of diverse personal values into media content.

\section{From Activism to Abstinence: The RoAd to MODERN CODES OF ETHICS}

Although objectivity and its accompanying requirement of nonparticipation represent current norms, these standards evolved from a contrary tradition of politically active journalism. American newspapers were inextricably entwined with politics throughout the

${ }^{15}$ See infra notes 253-54 and accompanying text (describing progressive muckraking journalism).

${ }^{16}$ See infra Part IV.D. 
eighteenth and nineteenth centuries. The partisan nature of the press emerged during the American Revolution, when newspapers helped mobilize popular opinion in favor of the war against England. ${ }^{17}$ The early American press broke down along fiercely political lines, reflecting close ties between editors and party machinery. ${ }^{18}$ These interlocking political relationships manifested themselves in aggressively partisan newspaper content. ${ }^{19}$ Since editors endeavored to advance the interests of their parties at all costs, political ideas and even vituperative debate abounded in early American newspapers. ${ }^{20}$ Such outspoken partisan publications

17 See James Aronson, The Press and the Cold War 11 (1990) (noting the press's contribution to the success of the Revolution); JEFFERY A. SMITH, PRINTERS AND PRESS FREEDOM: THE IDEOLOGY OF EARLY AMERICAN JOURNALISM $37-38$ (1988) (discussing the open partisanship of the press following the Revolution). Scholars invariably characterize the early American press as an intensely partisan institution and suggest that principles of impartiality and balance in journalism did not arise until the mid-nineteenth century at the earliest. It is interesting to note, however, that the carly printers in colonial America claimed impartiality as their defining characteristic. This impartiality, which grew out of the printers' contempt for political parties in England, withered in the face of the political passions and turmoil of the American Revolution as "[n]eutrality became all but impossible." Id. at 37.

${ }^{18}$ See HAZEL DICKEN-GARCIA, JOURNALISTIC STANDARDS IN NINETEENTH-CENTURY AMERICA 30-32 (1989) (discussing in detail the political role of the press in the first half of the nineteenth century). These ties reflected in part a financial imperative: newspapers could not survive without the revenues provided by political parties. Neither subscriptions nor advertising generated sufficient income to sustain a publication in the late eighteenth and early nineteenth centuries. Newspapers therefore turned to political parties for financial support, and, in return, opened their columns to the ideas and interests of party leaders. See DONNA L. DICKERSON, THE COURSE OF TOLERANCE: FreEdOM OF THE PRESS IN NINETEENTH-CENTURY AMERICA 61-62 (1990) (offering nonpecuniary reasons for party support of nineteenth-century newspapers); Michael E. MCGerR, THE Decline of POPUlaR POLITICS: The AMERICAN NORTH, 1865-1928, at 112 (1986) (noting the influence of partisan journalism on standardized news services).

Still, this relationship should not be viewed as a crass exchange of principle for profit, particularly since "[n]ewspaper editors rarely made large profits from their publishing ventures." Dickerson, supra, at 61 . Most editors not only shared an intellectual affinity with the political parties that underwrote their papers but also believed they were helping to shape the development of a fledgling republic. "Vital decisions were being made in foreign affairs, domestic activities, and economics by an infant democracy, and editors reasoned that their participation in these decisions was necessary if the democratic experiment was to work." Id. at 62.

${ }^{19}$ See Gerald J. Baldasty, The Nineteenth-Century Origins of Modern American Journalism, in THREE HUNDRED YEARS OF THE AMERICAN NEWSPAPER 407, 408-09 (John B. Hench ed., 1991) ("Partisan advocacy was the central content of these newspapers, and what we would call editorials today constituted the form of newspaper writing. Editors distrusted claims of neutrality in politics; rather, partisanship was deemed a badge of honor and integrity.") (footnote omitted).

${ }^{20}$ See DICKEN-GARCIA, supra note 18, at 71 (characterizing the content of the early 
often wielded enormous political clout. One recent study, for example, assigns the press an integral role in building a national consensus on behalf of the Constitutional Convention. ${ }^{21}$

This tradition of political activism began to weaken with the ascendancy in the 1830 s of inexpensive, middle-class papers that claimed independence from political parties and built their financial base around "large circulation and the advertising it attracted." The drive of this "penny press" to capture readers resulted in a significant shift in newspaper content, moving from the partisan, "idea-centered" model to an emphasis on the "event," which was thought more likely to engage a wide audience. ${ }^{23}$ In the latter half of the nineteenth century, newspapers gradually cut off formal ties with political parties. ${ }^{24}$

Still, the symbiosis between journalism and politics persisted. Editors doubled as congressmen, cabinet members, special political envoys, and even presidential candidates. ${ }^{25}$ Although the press increasingly repudiated political partisanship, this movement did not translate into neutrality in the news columns. ${ }^{26}$ Newspapers continued to take strong positions on issues in both news and editorial pages. ${ }^{27}$ As late as 1923, the editor of the Louisville Courier-Journal could still remark, upon surveying the landscape of

press as "idea-centered").

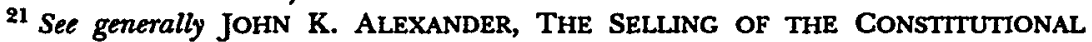
CONVENTION: A HISTORY OF NEWS COVERAGE (1990) (discussing in detail the role of newspapers and magazines in mobilizing popular support for the Constitutional Convention).

22 Michael Schudson, Discovering THE NEws 18 (1978). Schudson argues that this "penny press," in replacing the party press, fostered the "triumph of 'news' over the editorial and 'facts' over opinion, a change which . . . would lead, in time, to the journalist's uneasy allegiance to objectivity." Id. at 14 .

23 See DICKEN-GARCIA, supra note 18, at 82-83 (analyzing the rise of event-oriented reporting and the resulting difficulties encountered by the press).

${ }^{24}$ See generally Jeffrey Rutenbeck, Toward a History of the Ideologies of Partisanship and Independence in American Journalism, J. COMM. INQUIRY, Summer 1991, at 126, 126-39 (describing the movement by late nineteenth century American newspapers away from political partisanship).

25 From Horace Greeley to William Randolph Hearst, "every nineteenth-century journalist of note had powerful political influence." DICREN-GARCIA, supra note 18, at 31-82. Ten journalists, including New York Times editor Henry J. Raymond, were elected to the House of Representatives in 1864. See DONALD A. RITCHE, PREsS GALLERY: CONGRESS AND THE WASHINGTON CORRESPONDENTS 67 (1991).

${ }^{26}$ See Rutenbeck, supra note 24, at 135.

27 See Richard Streckfuss, Objectivity in Journalism: $A$ Search and a Reassessment, 67 JoURNALISM Q. 973, 982 (1990) (noting that, despite the rise of objectivity, newspapers in the 1920 s continued to infuse their news columns with policy positions). 
newspapers, that "[t]he leading dailies everywhere stand for something. They are rarely without aspirations." 28

As the press continued to assume the qualities of commercial institutions, however, elements of advocacy in journalism began to wane. Newspapers grew increasingly preoccupied with enhancing their circulation by appealing to as wide a readership as possible. ${ }^{29}$ With the number of one-newspaper cities rising dramatically in the 1920 s, editors found it necessary to transcend partisan lines. ${ }^{30}$ This concern spurred the birth of objectivity as a professional norm dictating a separation of facts from opinion in news reports. ${ }^{31} \mathrm{~W}$. Lance Bennett explained this development as follows:

Journalism, like most professions, developed a set of business practices first, then endowed those practices with a set of impressive professional rationalizations, and finally proceeded to rewrite its history in ways that made the practices seem to emerge, as if through immaculate conception, from an inspiring set of professional ideals. ${ }^{32}$

Commercial considerations thus laid the groundwork for the adoption of objectivity as a professional norm in the 1920s and 30 s. $^{33}$ In keeping with the marketing aims of publishers, objectivity required reporters to suppress personal opinions on the issues they covered and to strive toward impartiality and balance. ${ }^{34}$ The move towards impartiality had clear implications for the personal liberties of editors and reporters, for accompanying the ratification of objectivity was a conception of the reporter as a nonparticipant. ${ }^{35}$

${ }^{28}$ Id. (footnote omitted).

${ }^{29}$ See BAGDIKIAN, supra note 5, at $129-30$ (suggesting that the commercial imperative of attracting advertising revenue ushered in the era of objectivity); MrTCHell STEPHENS, A HistoRY OF NEWS 262 (1988) (explaining that neutrality served newspapers' need to "maintain a broadly based readership").

${ }^{30}$ See Streckfuss, supra note 27, at 982.

${ }^{31}$ See BAGDIKIAN, supra note 5, at 129-30 (explaining the need for newspapers to minimize political statements in order to appeal to mass audiences).

32 W. LANCE BENNETT, NewS: The Politics of Illusion 80 (1983).

35 See C. Edwin Baker, Advertising and a Democratic Press, 140 U. PA. L. REv. 2097, 2131 (1992) (concluding that the interlocking goals of boosting newspaper circulation and thereby generating greater advertising revenue were at least partly responsible for the rise of objectivity in journalism). The American Society of Newspaper Editors included impartiality among its defining principles in the Canons of Journalism promulgated in 1923. See Lynn W. Hartman, Standards Governing the News: Their Use, Their Character, and Their Legal Implications, 72 IOWA L. REV. 637, 639 (1987).

34 See BENNETT, supra note 32, at 78-80 (describing the expanding market of the American press and the accompanying need to standardize reporting).

${ }^{35}$ See MIRALDI, supra note 5, at 6 (stating that the "objective journalist is simply 
The imperative of nonparticipation remained largely unchallenged until the late 1960s and early 1970s, when issues such as America's involvement in Vietnam sparked a rebirth of political activism among journalists. Individual reporters and editors began bucking the conventions of objectivity by participating openly in political demonstrations and otherwise expressing their personal opinions in a public way:

A New York Times columnist and editor had made a stirring antiwar speech in Cambridge, Mass., where he declared: "We... got one president out and perhaps we can do that again." Soon afterward, 171 of Boston's editors, reporters, television and radio correspondents sent telegrams to the president and members of Congress declaring that "each day our military remains in Indochina is a further crime against mankind. As men and women of the American news media, we feel we must speak out." ${ }^{\text {36 }}$

At the same time, staff members within media organizations initiated a movement to acquire a voice in determining editorial policy. ${ }^{37}$ This ephemeral "newsroom democracy" movement saw the birth of "caucuses" among staff members seeking increased individual autonomy and the establishment of more journalism reviews concerned in part with tracking the media's performance. ${ }^{38}$

Owners and publishers generally resisted these overtures. ${ }^{39}$ Moreover, in the wake of the press's part in exposing Watergate ${ }^{40}$

an observer, who follows events ... [, b]ut he or she is not an active partner in shaping events or re-forming society").

${ }^{36}$ Harwood, supra note 7, at B6 (quoting a New York Times columnist and editor speaking at an antiwar rally).

${ }^{37}$ See ARONSON, supra note 17, at 287 (describing the movement for free expression in journalism as part of a more general revolt in the professional fields).

${ }^{38}$ See Randy Baker, Protecting the Press by Protecting the Joumalist: A Wrongful Discharge Action for Editorial Employees at Newspapers, 8 COMM./ENT. L.J. 1, 13 (1985).

${ }^{39}$ See ARONSON, supra note 17, at 287-88 (noting that owners' and editors' hostility to the newsroom democracy movement was tempered by the press's unique constitutional privilege). The newsroom democracy movement dissipated with the end of the Vietnam War. "By the mid 1970's [sic], most of the journalism reviews and newsroom caucuses had folded and the level of conflict between journalists and their employers had diminished substantially." Baker, supra note 38, at 14 . The causes for this decline included an unfavorable labor market for individual reporters and the general weakening of the activist movements that sprang from the 1960s. See id.

${ }^{10}$ This role may have been overblown. Although Washington Post reporters Bob Woodward and Carl Bernstein doggedly pursued the Watergate trail, many other newspapers ignored important developments in the scandal's early stages. The failure of the press as an institution to latch on to the story earlier prompted Post publisher 
and reporting critically on Vietnam (albeit at a very late stage in the war), news industry leaders expressed discomfort with the idea of wielding greater political influence. ${ }^{41}$ In a speech and subsequent magazine article published in 1974, Washington Post Chairperson of the Board Katherine Graham warned about the danger of "tendencies toward over-involvement" exhibited by the press during the Watergate crisis. ${ }^{42}$ Graham concluded that the media had become "'too much a party to events, too much an actor in the drama that was being played out." $\$ 43$

Many newspaper publishers apparently shared these sentiments. Following the lead of The Society of Professional Journalists, which had adopted conflict of interest restrictions in its 1973 Code of Ethics, ${ }^{44}$ newspapers began to promulgate codes of ethics designed to allay concerns about the "over-involvement" of journalists. The percentage of newspapers with nonparticipation guidelines increased dramatically in the 1970s. By 1983, seventy-five percent of news organizations responding to an Ohio University study reported that they had such directives in place. ${ }^{45}$

Katherine Graham to ask editor Ben Bradlee: "If this is such a hell of a story, where is everybody else?" See MICHAEL ScHUDSON, WATERGATE IN AMERICAN MEMORY 105 (1992) (quoting Katherine Graham). Yet popular perceptions credit the collective press with assuming a more aggressive stance with the advent of the Watergate scandal. Schudson argues that this "myth" has been fostered by "both government, which employs it to portray itself as unfairly besieged; and journalism, which uses it to present itself as a brave and independent social force." See id. at 117.

41 At a convention of the American Newspaper Publishers Association in 1976, both the general manager for the Associated Press and the ANPA chairman criticized the trend toward adversarial, investigative journalism inspired by Watergate. See id. at 114.

42 See ARONSON, supra note 17, at 297 (quoting Katherine Graham).

43 Id.; see also CHALMERs M. ROBERTS, IN THE SHADOW OF POWER: THE STORY OF THE WASHINGTON POST 442-43 (1989) (discussing Graham's criticism of postWatergate media practices).

11 The code of ethics adopted by The Society of Professional Journalists in 1973 includes this provision:

Secondary employment, political involvement, holding public office, and service in community organizations should be avoided if it compromises the integrity of journalists and their employers. Journalists and their employers should conduct their personal lives in a manner which protects them from conflict of interest, real or apparent. Their responsibilities to the public are paramount. That is the nature of their profession.

The Society of Professional Journalists, Sigma Delta Chi Code of Ethics (1973), reprinted in Hartman, supra note 33, app. C at 697.

${ }^{15}$ See Karen Schneider \& Marc Gunther, Those Newsroom Ethics Codes, ColuM. JourNalism REv., July/Aug. 1985, at 55, 55. This study contrasts with a 1974 Associated Press Managing Editors survey that found that less than $10 \%$ of 


\section{THE COSTS FOR JOURNALISTS: INSTITUTIONAL EFFORTS TO MANDATE OFF-DUTY NEUTRALITY}

In order to evaluate the merits of newspaper prohibitions on offduty conduct, one must consider what costs such restrictions might impose on individual journalists. A more affirmative way of framing the issue is to ask what values underlie the exercise of free speech and political participation rights. One classic value of speech lies in its ability to advance the search for knowledge or truth. ${ }^{46}$ This "marketplace of ideas" theory provides that the communication of ideas or sentiments constitutes a crucial social good. ${ }^{47}$ Restrictions on outside activity may undermine this value to the extent that the activity embraces a public component, such as participation in a political demonstration or service in the community.

In addition, several First Amendment theorists have suggested that speech warrants constitutional protection because it is vital to individual self-realization. ${ }^{48}$ Thomas Emerson, a leading First Amendment scholar, wrote that " $[t]$ he right to freedom of expression is justified first of all as the right of an individual purely in his capacity as an individual. ${ }^{\text {} 49}$ Expanding on this principle, C. Edwin Baker has advanced a "liberty theory" for freedom of

newspapers had such guidelines. See id.

A 1985 American Society of Newspaper Editors study appeared to confirm that abstinence was the norm at a majority of newspapers. Asked about a hypothetical ethical scenario in which an individual reporter made a monetary campaign contribution to a political candidate not on the reporter's beat, two-thirds of the newspaper editors surveyed said either that such activity would violate their paper's code or would be discouraged at the paper. Only $34 \%$ said the contribution would not violate their ethical code. See Richard Morin, Newsroom Ethics: How Tough is Enforcement?, J. MASS MEDIA ETHICS, Fall/Winter 1986-87, at 7, 8.

Even MTV, which markedly increased its coverage during the 1992 presidential campaign, has begun to embrace this norm. In September, the 24-hour music channel directed its employees engaged in campaign coverage to refrain from making significant contributions to politicians. See Judith Miller, But Can You Dance to It?: MTV Turns to News, N.Y. TIMES, Oct. 11, 1992, Magazine, at 30, 33 (describing MTV's efforts to avoid partisanship during the campaign).

${ }^{46}$ See EMERSON, supra note 11, at 7.

47 See, e.g., MARTIN H. Redish, Freedom of Expression: A CrITICAL ANALYSis 4548 (1984) (analyzing attacks on the marketplace of ideas theory and suggesting that the theory can be defended "as . . . a means by which the ultimate value of selfrealization is facilitated"); Irwin P. Stotzky, Foreword: The First Amendment and the Press, 34 U. MLAMI L. REV. 785, 786-87 (1980) (explaining the views of the proponents and critics of the "marketplace of ideas" paradigm).

${ }^{48}$ See, e.g., BAKER, supra note 11, at 52.53 (distinguishing between the use of speech for self-expressive and communicative purposes); EMERSON, supra note 11, at 4-5 (linking the achievement of self-realization with development of the mind).

19 EMERSON, supra note 11 , at 4. 
speech. ${ }^{50}$ Baker argues that "the [F]irst [A]mendment values of self-fulfillment and popular participation in change emphasize the speech's source in the self, and make the choice of the speech by the self the crucial factor in justifying protection." ${ }^{\text {51 }}$ Baker thus emphasizes speech's value to self-realization "independent of any expected communication to others. ${ }^{\mathrm{5} 2}$

A review of recent employment controversies centering on the propriety of activism by journalists indicates that enforcement of codes of ethics may preclude or chill speech activities important to self-definition. In most of these incidents, detailed below, employers had no indications that the reporters were using their position to advance a political or social agenda. Nonetheless, their activism brought swift condemnation from their media employers.

\section{A. Fueling the Controversy: Supreme Court Reporting and Abortion-Rights Advocacy}

The controversy that catalyzed recent scrutiny of media conflict of interest standards grew out of an April 1989 demonstration in which several hundred thousand pro-choice advocates converged upon Washington. ${ }^{53}$ In what she believed would be an anonymous public act, New York Times Supreme Court reporter Linda Greenhouse joined in the march for abortion rights. ${ }^{54}$ Reporters from other papers, including the Washington Post, also attended the demonstration in their individual capacities as citizens. ${ }^{55}$ When editors at the Times learned of Greenhouse's participation, they rebuked her and warned that such activity violated a longstanding policy at the paper barring staff members from engaging in outside activities that endangered the credibility and independent standing of the paper. ${ }^{56}$

${ }^{50}$ See BAKER, supra note 11 , at 47 .

51 Id. at 52.

$52 \mathrm{Id}$. at 53.

53 See Robin Toner, Abortion Marchers Gather in Capital, N.Y. TIMES, Apr. 9, 1989, at A1, A28.

54 See Stephanie Saul, Judgment Call: Do Reporters Have a Right to March?, ColuM. JOURNALISM REV., July/Aug. 1989, at 50, 50.

55 See Randolph, supra note 7, at $\mathbf{C 1}$.

56 See Jones, supra note 7, at 28 . The paper's account of its in-house controversy included the following articulation of Times policy: "The integrity of The Times requires that its staff members avoid employment or any other undertaking . . . that creates or appears to create a conflict of interest with their professional work for The Times or otherwise compromises The Times's independence and reputation." Id. In a subsequent article in a communications journal, six New York Times reporters argued 
The Times refrained from further disciplinary action, however, allowing Greenhouse to continue to cover abortion on the Supreme Court beat. ${ }^{57}$ But the Post adopted a more rigid position with respect to staff members who marched in the demonstration. In keeping with its broad prohibition on outside activity, however unrelated to a reporter's beat, the newspaper condemned the participation of all newsroom personnel who took part in the demonstration. ${ }^{58}$

The reactions of the Washington Post and the New York Times sparked a public dialogue in the press about restrictions on the political activities of media personnel, prompting newspapers to reexamine their codes of ethics governing the off-duty conduct of their staffs. ${ }^{59}$ Several aspects of Greenhouse's participation generated heightened scrutiny of media standards. First, she had engaged in activism on an issue that she wrote about regularly in her professional capacity as a Supreme Court reporter. Although the breadth and severity of codes of ethics vary from paper to paper, media organizations appear united in their refusal to allow staffers to participate in issues that implicate their area of cover-

that newspapers should not deny their staff members the right to participate in marches or political demonstrations. See Joan Cook et al., March, They Say, THE PROF. COMMUNICATOR, Winter 1989, at 15, 15 (contending that restrictive codes of ethics "are inherently tools to keep staff dissent under tight control and to provide opportunities to suppress independent-minded workers").

${ }^{57}$ On the very same day the Times published its account on the controversy, the paper also ran a story by Greenhouse about an abortion case pending before the Supreme Court. See Linda Greenhouse, A Seemingly Routine Missouri Case Takes Abortion Issue to High Court, N.Y. TIMES, Apr. 16, 1989, at 28.

${ }^{58}$ See Jones, supra note 7, at 28 . In a newsroom memo, Post editors reiterated to staff members that "it is unprofessional for you . . . to take part in political or issue demonstrations, no matter on which side or how seemingly worthy the cause. It is the choice we make when we choose to work in this business and for this newspaper." Randolph, supra note 7, at $\mathrm{Cl}$ (quoting a memo to the Washington Post staff written in response to the discovery that a number of reporters and editors had participated in the pro-choice march). The paper demanded that those who marched "recuse [themselves] from any future participation in coverage of the abortion issue." See Jones, supra note 7, at 28.

${ }^{59}$ See, e.g., Saul, supra note 54, at 50-52 (exploring reporters' varying views on political participation and its effect on the appearance of neutrality); Erich Lichtblau, Reporter's Notebook: Journalistic Neutrality Oflen Has A Dark Side, L.A. TIMES, Oct. 22, 1989 , at B3 (discussing the dilemmas faced by reporters in seeking to maintain their objectivity); Laurence Zuckerman, To March or Not to March: Reporter's Own Beliefs About Abortion Become an Issue, TIME, Aug. 14, 1989, at 45, 45 (addressing the responses by news organizations to their reporters' participation in abortion-related political activity). 
age. ${ }^{60}$ Second, and in spite of her expectations, Greenhouse was unable to keep her participation shrouded in anonymity. ${ }^{61}$ Finally, the cause for which Greenhouse and other reporters were demonstrating is entangled in an explosive political controversy.

Although Greenhouse was only disciplined, not fired, the controversy surrounding her activity provides a good example of how codes of ethics may chill or preclude expressive conduct important to self-realization. Her attendance at the demonstration was not designed to use her status as a New York Times reporter to mobilize support for the pro-choice movement. Nor was she engaged in a brand of participatory journalism that personalizes news coverage in an effort to convey a strong point of view. Rather, Greenhouse's own comments about her involvement suggest her activity was rooted in self-definition:

It's the first public act I've engaged in in the twenty-one years I've been at the Times. ... I honestly thought it was just a few steps removed from the privacy of the voting booth. It's not as if I was marching under a banner that said 'New York Times Reporter for Choice.' I was just another woman in blue jeans and a down jacket. ${ }^{62}$

This description conforms to a paradigm of political activism derived from Baker's liberty theory of freedom of speech. Under this theory, an antiwar demonstrator may protest not necessarily out of a belief that her speech will influence foreign policy, but instead because it "expresses and further defines [her] identity." 63 Like this hypothetical protestor, a reporter may find value in attending an abortion-rights march "without any expectation ... that it will successfully communicate anything to people in power. ${ }^{n 64}$

The self-realization value of this kind of speech becomes clear in comparing the nature of Greenhouse's off-duty involvement to the behind-the-scenes advocacy of a previous New York Times Supreme Court correspondent. In 1963, as Solicitor General Archibald Cox was preparing to argue a crucial reapportionment

${ }^{60}$ See Jones, supra note 7, at 28.

61 The off-duty advocacy of journalists may often go unreported. See Carol Emert, Abortion-Rights Dilemma: Why I Didn't March, WASH. PosT, Apr. 12, 1992, at C2 (explaining that several reporters who were to take part in an April 1992 abortionrights rally advised Emert to attend since "[n]obody's going to know anyway").

${ }^{62}$ Saul, supra note 54, at 50-51 (quoting New York Times reporter Linda Greenhouse).

63 BAKER, supra note 11 , at 53 .

64 Id. 
case before the Supreme Court, Times reporter Anthony Lewis stepped out of the role of impartial observer and became an advocate for a legal position in a lobbying effort to persuade Cox of the merits of the "one-man, one-vote standard. ${ }^{65}$ Lewis successfully prodded Cox into embracing this position before the Court. ${ }^{66}$ This incident underscores the distinction between advocacy flowing directly from reporting assignments and off-duty conduct separable from professional duties. ${ }^{67}$

\section{B. No Abortion Activists Need Apply: Media Employer Discharges for Involvement in the Abortion Debate}

Within a year of the controversy surrounding the abortion-rights march in Washington, at least four other newspaper employees were fired for engaging in abortion-related political activity. These incidents illuminate the considerable tension between current journalistic standards and individual rights. The abortion context presents a particularly vexing dilemma for media enterprises, for the activities at issue implicate not only freedom of speech but also religious liberty. ${ }^{68}$

65 See Tom Goldstein, The News AT ANy Cost 35 (1985).

${ }^{66}$ See id.; VICTOR S. NAVASKY, KENNEDY JUSTICE 302 (1977). Lewis's initial intervention was limited to conversations with Attorney General Robert F. Kennedy in which Lewis warned Kennedy that "it would be a tragedy" for the Justice Department to oppose the standard. See id. at 316. When this approach produced unsatisfactory results as reflected in the galleys of Cox's brief to the Court, Lewis drove to Cox's home just days before the brief was scheduled to be filed and made his arguments directly to the Solicitor General. See id. at 317. These pleas apparently bore fruit in the final draft of the brief presented to the Court. In his book on the Kennedy Justice Department, Navasky writes that Lewis, in abandoning "any pretense at objectivity," played a key role in influencing the government's position. See id.; see also GoLDSTEIN, supra note 65, at 35 (contending that Lewis exceeded "the bounds of appropriate journalism" by engaging in overt advocacy).

67 Yet another incident involving a reporter and the Supreme Court occurred in 1991 when Baltimore Sun reporter Arch Parsons, upon learning that President Bush was contemplating the nomination of Clarence Thomas to the Court, privately lobbied NAACP executive director Benjamin Hooks to refrain from condemning Thomas. Through a conservative contact, Parsons provided the White House with information as to the neutral position Hooks and the NAACP might take on the nomination. Parsons failed to inform his editors of this activity even though he subsequently wrote almost $\mathbf{4 0}$ stories on Thomas for the paper. By the time Parsons' activity came to light with the publication of a book on the Thomas nomination in June 1992, Parsons had left the paper. Nonetheless, the Sun reported the incident extensively, and its editor condemned Parsons' attempt to "manipulate the outcome" of the nomination. See Terence A. Dalton, Crossing the Line Between Reporting and Lobbying, WASH. JOURNALISM REV., Sept. 1992, at 13, 13.

${ }^{68}$ See generally Mark Weston, Faith and Abortion: Where the World's Major Religions 
In at least one instance, a newspaper employee successfully challenged application of the paper's code of ethics to her activities. In July 1989, a newsroom receptionist for the Milwaukee Journal was fired because of her participation in anti-abortion activities, which the paper claimed were in violation of its code prohibiting outside activities. ${ }^{69}$ After the receptionist lodged a complaint with a state labor agency, the Journal settled the case for damages and back pay, acknowledging that it had "stretched the code too far" in applying it to the receptionist. ${ }^{70}$ But the paper insisted that it would continue to enforce the prohibition with respect to all editors and reporters, irrespective of whether they covered abortion-related issues. $^{71}$

In April 1990, a small Iowa daily dismissed two of its editors who refused to accede to the paper's demands that they quit a prolife group. ${ }^{72}$ The Fairfield Daily Ledger barred participation in political activities likely to generate news publicity. ${ }^{73}$ The paper argued that the anti-abortion activity compromised its credibility in the eyes of its audience. ${ }^{74}$ Six months later, the former employees sued the paper in Federal District Court in Des Moines, alleging that the paper had failed to "reasonably accommodate" their religious convictions in violation of the Civil Rights Act. ${ }^{75}$ The paper subsequently reached a $\$ 35,000$ settlement with the former editors. ${ }^{76}$

Several other incidents suggest a lack of consensus among newspapers as to whether abortion-related activity fatally undermines ethical standards. In July 1989, the Vero Beach Press-Joumal

Disagree, WASH. POST, Jan. 23, 1990, at 12 (discussing the views on abortion of various religious groups).

${ }^{69}$ See Abortion Foe Wins Action Against Paper, CHI. TRIB., Dec. 7, 1989, at 3; AntiAbortion Activist Settles Dispute, PressTIME, Mar. 1990, at 58, 58.

${ }^{70}$ See Milwaukee Journal Settles with Secretary, UPI, Dec. 5, 1989, available in LEXIS, Nexis Library, UPI File.

${ }^{71}$ See Abortion Foe Wins Action Against Paper, supra note 69, at 3.

72 See Abortion Foes Fired, USA TODAY, Apr. 11, 1990, at 3A; 2 Iowa Editors Ousted for Anti-Abortion Role, N.Y. TIMES, Apr. 11, 1990, at A19 [hereinafter Editors Ousted]. The two individuals, John Kennedy and Terri Lambertsen, had been employed at the Fairfield Ledger as news editor and people editor, respectively. Kennedy and Lambertsen were active in Southeast Iowa Pro-Lifers. See id.

73 See Editors Ousted, supra note 72, at A19.

74 See id.

75 See Leslie Bates, Suit Defends Fired Pro-Life Editors, WASH. JouRnalisM REv., Mar. 1991, at 16, 16. For a discussion of the possibility of using Title VII in this regard, see infra part IV.C.

${ }^{76}$ See Iowa: Des Moines, USA TodAY, Apr. 21, 1992, at 6A. 
fired an education reporter who publicly endorsed abortion rights. ${ }^{77}$ The paper had concluded that the presence of a vocal pro-choice advocate on the staff "undermined the paper's credibility," even though the reporter had affirmatively sought to ensure that she would not be assigned to cover abortion-related issues. ${ }^{78}$ At the Louisville-Courier Journal, meanwhile, a copy editor was prohibited from engaging in "sidewalk counseling" outside abortion clinics, but he was allowed to serve as a counselor at a pregnancy center. ${ }^{79}$

The majority of the journalists involved in these incidents were not covering issues related to abortion. Their employers therefore appeared to be acting not out of a desire to preserve the neutrality of abortion-related content, but rather to insulate themselves from charges of bias and to avoid offending readers. In seeking to ensure moral neutrality on abortion, however, newspapers deny journalists the right to act upon deep-seated convictions about religion, personal autonomy, and human dignity. ${ }^{80}$ The importance of these convictions to self-definition weighs in favor of accommodating both pro-life and pro-choice activities to the extent that they do

77 See Florida Reporter Fired for Abortion Statements, Presstime, Sept. 1989, at 61, 61. The reporter, Vicky L. Hendley, had been quoted in several newspapers as an advocate of abortion rights and had also sent pro-choice letters, along with small wire coat hangers, to 160 Florida lawmakers. Newspaper officials said her actions breached the paper's policy barring journalists from publicly voicing their political views without first obtaining approval from supervisors. See id.; David Shaw, Can Women Reporters Write Objectively on Abortion Issue?, L.A. TIMEs, July 3, 1990, at A23.

${ }^{78}$ See id. at A23.

79 See John Hughes, Abortion and Joumalistic Objectivity, CHRISTIAN SCI. MONITOR, July 18, 1990, at 19 .

${ }^{80}$ One Chicago Tribune reporter frames the issues this way: "To me, the struggle for abortion rights is as important to women as the struggle against slavery. This isn't about whether they're going to build some bridge downtown. This is about my body." Zuckerman, supra note 59, at 45 (quoting anonymous Chicago Tribune reporter). Such passionate convictions may be crucial to how an individual defines her identity. Yet newspapers appear insensitive to this possibility in subordinating the political participation rights of journalists to concerns about the appearances of neutrality. At a recent panel discussion organized by the National Lesbian and Gay Journalists Association, one audience member asked New York Times managing editor Joseph Lelyveld whether gay journalists should be allowed to participate in the gay community they wrote about. Lelyveld replied: "Being gay is not in itself a political position. It's an identity. I wouldn't have any problem with a person who marched in a Gay Pride parade covering gay affairs." See Don't Quote Me, WASH. JouRnalisM REV., Sept. 1992, at 13, 13 (quoting Joseph Lelyveld). One can agree with Lelyveld's position on community participation by gay journalists and still question his apparent inclination to treat advocacy of important political positions as separate from an individual's identity. 
not impinge upon job performance in a tangible way. Moreover, the presence of advocates on both sides of the controversy would promote editorial diversity and thereby reduce misconceptions in the press about abortion. ${ }^{81}$

\section{The Wide Net of Restrictions on Off-Duty Conduct}

As the abortion-related incidents described above suggest, newspaper management rejects the idea of reporters taking sides on public controversies. This discomfort often manifests itself in conflict-of-interest standards that sweep broadly, encompassing everything from bids for elective office to personal relationships. ${ }^{82}$ The standards have been applied in numerous instances where journalists were engaging in activity unrelated to their area of coverage.

Most media employers object to an employee's active involvement in politics or community affairs. ${ }^{83}$ The Troy Times Record in

81 See David Shaw, Abortion Foes Stereotyped, Some in the Media Believe, L.A. TIMES, July 2, 1990, at A1 (discussing views of pro-life activists held by journalists); infra notes $\mathbf{2 7 4 - 8 5}$ and accompanying text.

82 In addition to overt political or community involvement, journalists have encountered problems with ethical restrictions as a result of personal relationships with public officials. An extreme example of this kind of conflict occasioned the New York Times's firing in 1977 of a former Philadelphia Inquirer reporter. While covering a Philadelphia mayoral race, the reporter had sustained a romantic relationship with a state senator known to be a close ally of one of the candidates. See Tony Schwartz \& Lucy Howard, A Philadelphia Story, NEwSWEER, Nov. 14, 1977, at 48, 48.

In 1991, a Chicago Sun-Times reporter was forced to resign amid concerns about his relationship with the City Treasurer. The reporter, Ray Hanania, was initially transferred off his city hall beat when he informed his editors that he was dating Treasurer Miriam Santos. The controversy grew when complaints surfaced that Hanania had provided political advice to Santos. See Howard Kurtz, You Can't Date City Hall: Chicago Reporter is Out of a Job, WASH. POST, Nov. 16, 1991, at D1. Hanania sued the paper and its editor, seeking compensatory and punitive damages on the grounds that he was unjustly forced to resign and that the paper's explanation of the resignation was defamatory. See Former Reporter Sues Sun-Times, CHI. TRIB., Nov. 21, $1991, \S 3$, at 3.

${ }^{83}$ In addition to media norms, other barriers to political activity may arise. Consider the case of William Branch, a general assignment reporter for a Sacramento television news station. See Branch v. FCC, 824 F.2d 37, 39 (D.C. Cir. 1987), cert. denied, 485 U.S. 959 (1988). In 1984, Branch, who had participated actively in the incorporation of Loomis, California as a town, expressed a desire to seek election to the Loomis town council. Under a federal "equal time" statute, 47 U.S.C. \$ 315(a) (1982), however, Branch's station would have been compelled to provide the same amount of television time each day to his opponents, a possibility that the station understandably regarded as impracticable. See id. Consequently, Branch was informed that he would have to leave his reporting job, at least temporarily, with no guarantee of future employment, if he wanted to run in the election. Branch 
upstate New York, for example, dismissed one reporter who had been selected as an alternate delegate to the 1980 Democratic National Convention, even though she never covered politics. ${ }^{84}$ Likewise, the Knight-Ridder chain of papers dismissed a Minnesota "Today's Living" section editor upon her decision to seek election to the city council. ${ }^{85}$ In both of these instances, the employees in question were acting on personal values in a manner distinct from their job performances. That they were discharged in spite of this separation underscores the concern among newspaper employers that employee activism might in some way link them to partisan political causes.

Often, ethics codes reach even further than partisan activity, narrowing a journalist's sphere of off-duty conduct to neutral terrain even as to issues that are not morally or politically charged. The Philadelphia Inquirer once found a violation of its ethics code in a film critic's decision to sign a petition protesting the deteriorated condition of a theater. ${ }^{86}$ Moreover, a Seattle Times columnist who placed his name on the ballot for the nonpartisan post of local water commissioner was informed that he would lose his job if he won the election; the paper's editors claimed that the columnist, John Hinterberger, could not remain an objective journalist while serving as a city official. ${ }^{87}$ Determined to keep his job at the paper, but already locked in as a candidate for the election, Hinterberger implored his readership not to vote for him, and, in

dropped out of the race but subsequently sued the FCC, challenging its determination that the equal time statute applied to him, as well as the constitutionality of the statute. The D.C. Circuit, in an opinion written by Judge Robert Bork, rejected Branch's challenges, finding no support in either the language or legislative history of the statute for the proposition that newscasters are exempt from its requirements. See id. at 41-47. Although Branch's appearances comprised part of a "bona fide newscast," which is expressly exempted by the statute, the court found that the exemption does not apply where such appearances are unrelated to the subjects covered by the newscast. See id. at 45 . The court also noted that "many people find it necessary to choose between their jobs and their candidacies." Id. at 48.

84 See H. EUGENE GOODWIN, GROPING FOR ETHICS IN JOURNALISM 76 (1983). The reporter, Susan O'Brien, said that, as an employee, she "wrote a three-times-a-week hot line column, typed up bowling scores, put together a weekend calendar, and sat in for the receptionist when she went to lunch." Id. (quoting Susan O'Brien).

${ }^{85}$ See id. at 75-76.

${ }^{86}$ See Saul, supra note 54, at 52. The Inquirer adopted a policy in 1977 instructing staffers to "be careful not to offend or give the wrong impressions to members of the public by blatantly espousing or expressing viewpoints on public issues." Id. (quoting Inquirer policy).

${ }^{87}$ See Schneider \& Gunther, supra note 45 , at 56. 
what must have been one of the most bizarre election races in recent memory, engineered his own defeat. ${ }^{88}$

A more widely reported instance of community involvement by a journalist occurred in 1983 when Jacqueline B. McClary, a reporter for the Knoxville News-Sentinel, won election to a local board of education in a neighboring community where her children attended school. ${ }^{89}$ McClary said she ran for the position as a concerned mother and citizen. She was dismissed after the newspaper determined that this kind of community service ran afoul of a company policy that "barred news employees from 'any political activity that could raise questions as to the newspaper's objectivity." 90 The paper's justification rang hollow for two reasons. First, McClary never covered news occurring in the town or county she sought to serve as a school board member. Second, the newspaper allowed its editor to head a local parking authority and its conservation reporter to serve on a national park commission. ${ }^{91}$ In an ensuing legal dispute flowing from a union grievance, an arbitrator found in favor of McClary on these grounds. ${ }^{92}$

These incidents further illustrate the manner in which prevailing codes of ethics curtail or chill the political and community participation of individual journalists. Restrictive codes of conduct infringe upon the individual liberty of journalists, reflecting a failure to reconcile a reporter's professional status with her rights as a citizen. ${ }^{93}$ In illustrating these costs, the foregoing discussion has

${ }^{88}$ See id. An arbitrator subsequently struck down the paper's ban on political candidacies. See id.; see also infra notes 175-78 and accompanying text.

${ }^{89}$ See Jonathan Friendly, Reporter Dismissed After Election to School Board, N.Y. Times, June 15, 1983, at A16. at 41 .

${ }^{90}$ Richard Haitch, Follow-Up on the News: Citizen Rights, N.Y. TiMES, Apr. 1, 1984,

91 See Sandra R. Gregg, Reporter's Firing Raises Rights Issue, WASH. POST, June 13, 1983, at A2.

92 See Knoxville Newspaper Guild, Local 976 v. Knoxville News-Sentinel Co., A.A.A. No. 3030006983 (June 10, 1983) (Duff, Arb.) (on file with the Newspaper Guild); see also GoLDSTEIN, supra note 65, at 40-41 (discussing McClary's dismissal from and subsequent return to the newspaper, and noting that the editor resigned from the parking authority).

93 A recent incident in California highlighted this dichotomy between journalism and citizenship. The mayor of Rancho Palos Verdes barred Enrica Stuart, the publisher-editor of a small partisan paper that routinely criticized the city council, from asking questions of council members at public hearings. "You're either a member of the public or a member of the press," the mayor said. See Waters, supra note 1, at B3 (quoting Rancho Palos Verdes Mayor Mel Hughes). After the American Civil Liberties Union intervened, the mayor lifted the prohibition directed against Stuart. See id. 
necessarily touched on the rationales underlying the enactment and enforcement of such codes. The following section takes up this issue in greater detail, exploring whether these justifications make sense independent of their impact on the lives of newsroom personnel and whether enforcement of the codes has been true to the justifications.

\section{A CREDibility GaP: Evaluating RESTRICTIONS ON THE OFF-DUTY AFFAIRS OF JOURNALISTS}

\section{A. The Lack of a Persuasive Justification}

In propounding rationales for their ethical guidelines, newspapers insist that limits on the activities of their employees are necessary to eliminate real or apparent conflicts of interests. These twin objectives point to two principal policy justifications for the restrictions. First, most codes of ethics proclaim the imperative of journalistic objectivity, suggesting that abstention from off-duty activities is necessary to avoid bias. American journalism remains institutionally committed to the belief that objective reporting practiced by independent journalists will produce the most desirable media content. A second rationale lies in the need to preserve what newspapers generally characterize as their institutional credibility. Most media professionals claim that the mere appearance of an ethical conflict will be harmful insofar as it may lead readers to believe, even if erroneously, that content has been skewed.

\section{Objectivity as a Rationale}

The first of these two rationales necessarily entails some discussion of the merits of objectivity as the defining philosophy of modern American journalism. Commentators have increasingly recognized that objectivity itself is unattainable insofar as it aspires to produce news accounts entirely free from personal biases. ${ }^{94}$ Journalism itself is an inherently subjective endeavor. ${ }^{95}$ Mitchell Stephens has noted that "[a] bias of sorts appears the moment the flow of life is broken down into discrete 'events,' those events in

94 See MIRALDI, supra note 5, at 15 (stating that "[i]f there is any agreement on objectivity, it is this: to conceive of even the ideal of objectivity as the lack of bias is to misconceive it").

95 See BAGDIRIAN, supra note 5, at 179 (stating that "[e]very basic step in the journalistic process involves a value-laden decision"). 
turn broken down into discrete 'facts,' and a few of the infinite number of possible facts singled out as sufficiently compelling to be newsworthy. ${ }^{n 66}$

The process of reporting and writing news entails subjective decisions such as choosing the lead and angle of a story, selecting individuals to interview and quote, and assigning value-laden adjectives to events and institutions. ${ }^{97}$ These decisions "are all influenced by the personal history [the reporter] brings to his work." 98 Ironically, the techniques associated with objectivity may provide a means of cover for reporters who seek to promote a certain viewpoint in their news accounts. For example, several editors and reporters have acknowledged the practice of "shopping" for opinions consistent with their own. ${ }^{99}$ In the course of this process, "[i]nformation that is inconsistent with the slant of their stories is discarded. ${ }^{100}$ This practice illustrates how an article that purports to be free from a reporter's personal biases may subtly embody those biases.

Nonetheless, proponents of objectivity who concede the elusiveness of absolute neutrality often stress the virtues of objectivity as a theoretical ideal to which all reporters should aspire. ${ }^{101}$ In this regard, it is worth noting first that the term "objectivity" originally referred to the application of demanding scientific techniques to news reporting. ${ }^{102}$ In a probing article on

${ }^{96}$ STEPHENS, supra note 29, at 264.

97 See Bill D. Moyers, The Press and Government: Who's Telling the Truth?, in MASs MEDIA IN A FREE SOGIETY 16, 18 (Warren K. Agee ed., 1969) ("[O]f all the great myths of American journalism, objectivity is the greatest."); Baker, supra note 33, at 2137 (discussing criticism of objectivity deriving from media's "gate-keeper' role").

${ }^{98}$ Donald McDonald, Is Objectivity Possible?, in ETHICS AND THE PRESs 69, 70 (John

C. Merrill \& Ralph D. Barney eds., 1978).

99 See LAWRENCE C. SOLEY, THE NEWS SHAPERS: THE SOURCES WHo EXPLAIN THE News 24 (1992).

${ }^{100}$ Id. Los Angeles Times Washington bureau chief Jack Nelson describes the practice as follows: "When you are going to make an opinionated kind of statement, particularly in the news columns, editors insist you attribute it to someone other than yourself-so you go shopping." Id. at 24-25 (quoting Jack Nelson).

101 See Saul, supra note 54, at 51. Then Washington Post ombudsman Richard Harwood frames the issue this way:

We have spent the last fifty years trying to achieve a professional status in our society in which we approach the events we write about with what we hope would be the disinterestedness of a scientist. ... That's impossible and I recognize it, but that's the attitude of mind we should have and that's the goal we should be after.

Id. (quoting Richard Harwood).

102 See Streckfuss, supra note 27, at 974. 
the origins of objectivity, Richard Streckfuss explains that objectivity as originally conceived "was viewed not as something simple-minded and pallidly neutral, but as a demanding, intellectually rigorous procedure holding the best hope for social change. ${ }^{n 103}$ Theorists such as Walter Lippmann saw objectivity as a means of breaking through the manipulative use of facts by publicists to arrive at truth. According to Lippmann, the virtues of an objective journalist should include "the habits of ascribing no more credibility to a statement than it warrants." 104 Newspapers, however, seized upon weakened strains of objectivity as a means of confronting a changing economic climate that necessitated broad, nonpartisan appeals to readers. Reflecting this "diluted" form of objectivity, a 1935 journalism textbook explained that " [r] eporters for the most part write entirely objectively and keep themselves and their opinions out of their stories." 105

The evolution of modern objectivity has led to just the sort of manipulation that the original objectivity theorists feared. The common journalistic practices of relying overwhelmingly on official sources and of accepting their statements without serious challenge are well documented: studies indicate that reporters rely heavily on "government sources who are primarily men in executive positions," hindering the ability of the media to achieve the objectives of diversity and pluralism. ${ }^{106}$ At the extreme, undue reliance on official sources of information produces a situation in which "the ethic of objectivity is perverted into an ideology through which the government controls the press. ${ }^{\text {107 }}$ Even current practices of objectivity produce an ideological bias toward the status quo and

103 Id. at 973.

$104 I d$. at 978 (quoting WALTER LIPPMANN, LIBERTY AND THE NEWS 56 (1920)).

105 Id. at 982 (quoting PHILIP W. PORTER \& NORVAL N. LuXON, THE REPORTER AND THE NEWS 61 (1935)).

${ }_{106}$ See Jane Delano Brown et al., Invisible Power: Newspaper News Sources and the Limits of Diversity, 64 JoURNALISM $Q .45,53$ (1987).

107 Jeffrey B. Abramson, Four Criticisms of Press Ethics, in DEMOCRACY AND THE MASS MEDIA 229, 254 (Judith Lichtenberg ed., 1990). One aspect of government control is its ability to frame the debate about important policy issues and controversies in its own terms rather than in terms independently arrived at by the press. During the Gulf War, for example, the press unquestioningly embraced many of the assumptions and value-laden vocabulary of the U.S. military in reporting on the war. See Robert Jensen, Fighting Objectivity: The Illusion ofJournalistic Neutrality in Coverage of the Persian Gulf War, J. COMM. INQUIRY, Winter 1992, at 20, 30 (arguing that war coverage was inadequate insofar as its overriding characteristic was that "it accurately conveyed the words being spoken by those running the war"). 
undermine the ability of the press to act as a check on government. ${ }^{108}$

In spite of these drawbacks, objectivity remains a cornerstone of most codes of ethics in the news industry. Yet objectivity may operate to foreclose serious consideration of ethical dilemmas through the belief that performing the rituals of objectivity automatically leads to ethical journalism. ${ }^{109}$ In this respect, objectivity "conveniently frees journalists from responsibility for looking beyond competing arguments to find the truth." 110 Moreover, when official sources are unavailable to provide or validate an alternative viewpoint or criticism of government action, such positions may simply go unreported. ${ }^{111}$ These practices suggest a troubling irony: codes of ethics that enshrine objectivity and detachment may actually hinder the realization of ethical and truly independent journalism. Allowing a dubious theoretical norm to overwhelm individual attributes runs the risk of producing both individual reporters who are lacking in humanity and empathy and a system of journalism that refuses to broach the moral implications of news stories. ${ }^{112}$ A reporter's passion and personal values may

${ }^{103}$ See BENNETT, supra note 32, at 81-84 (arguing that objectivity promotes narrow political messages in the news and tempers the adversarial role of the press); Richard Delgado, The Language of the Arms Race, 64 B.U. L. REV. 961, 983 (1984) (contending that "the journalistic convention of objectivity ensures that the messages of the institutional speakers get through relatively unscathed, thereby reaffirming the legitimacy of those institutions and their communications"); see also infra notes 269-67 and accompanying text (further discussing the impact of objectivity on the checking function of the media).

${ }^{109}$ See John C. Merrill, Is Ethical Journalism Simply Objective Reporting?, 62 JOURNALISM Q. 391 (1985). Merrill found that 41 of 50 reporters equated objectivity with ethical performance. See id. at 393. An earlier study found similarly that "[f]or most [journalists], it is not an exaggeration to say that ethics equated with 'objective' news coverage." Rilla Dean Mills, Newspaper Ethics: A Qualitative Study, 60 JOURNALISM Q. 589, 594 (1983).

${ }^{110}$ STEPHENS, supra note 29 , at 267.

111 See MARR HERTSGAARD, ON BENDED KNEE 30 (1988). At the height of the IranContra scandal, for example, the press virtually ignored the possibility of impeachment proceedings against President Reagan because Congressional democrats were reluctant to discuss such action. Hertsgaard notes that "[j]ournalists later explained that to raise the question of impeachment before Congress did would have constituted 'advocacy' journalism." Id. at 333.

112 This potential cost of objectivity and detachment should not be underestimated. History has seen numerous instances in which journalists, either individually or collectively, appeared to have lost their moral bearings and allowed themselves to be exploited by tyrannical regimes. In the 1930 s, for example, Walter Duranty, the Moscow correspondent for the New York Times, virtually ignored the famine in the Soviet Ukraine that took millions of lives under the Stalinist program of forced 
fuel the kind of aggressive reporting that often appears to be the exception in American journalism. ${ }^{113}$

collectivization. Duranty, who blindly accepted Stalin's propagandistic claims, once said that he refused "to be sidetracked by moral issues or to sit in judgment on the acts of individuals or of states." S.J. TAYLOR, STALIN'S APOLOGIST 6-7 (1990) (quoting Walter Duranty). It can be argued, of course, that Duranty's reporting in no way met the standards of objectivity as a theoretical ideal.

On a broader institutional level, the press failed to cover adequately several of the more momentous events and issues of the twentieth century. During the Holocaust, for example, the media's excessive skepticism about reports of Nazi atrocities caused newspapers to bury or ignore such reports and thereby "helped the Nazis cover up the truth until late in the war." Evelyn Kennerly, Mass Media and Mass Murder: American Coverage of the Holocaust, J. MAss MEDIA ETHics, Fall/Winter 198687 , at 61,68 . Kennerly argues that the practice of objectivity not only enabled the State Department to with hold meaningful information from a deferential American press corps but also foreclosed a compassionate response to reports of the Nazi extermination campaign. See id. at 69 (suggesting that "in cases of human need, the ethic of objectivity should not be allowed to stand in the way of the ethics of compassion"). Perhaps the press would have been more willing to report on the Nazi horrors had the U.S. Government validated the issue by publicly condemning the war against the Jews and other minority groups.

The shortcomings of modern objectivity were also evident in the media's reporting on Senator Joseph McCarthy, who effectively manipulated the press to serve his immoral ends. See STEPHENS, supra note 29, at 268 (discussing how much of the reporting on McCarthy's "pseudo-lists of pseudo-Communists" failed to probe for the truth). Alden Whitman, a New York Times assistant copy editor who himself fell victim to McCarthyism, labelled this failure "one of the country's greatest disgraces. Moral issues were involved, but they weren't seen that way at the time." VICTOR $S$. NAVASKY, NAMING NAMES 66 (1981) (quoting Alden Whitman).

In a now-infamous incident in 1983, Americans got a taste of detached journalism in its most extreme form when a local television reporter and his cameraman watched passively for $\mathbf{3 7}$ seconds as an unemployed and distraught Alabama man set himself ablaze. See GolDSTEIN, supra note 65, at 29. Several incidents that stand as counterpoints to this example occurred during the recent ethnic turmoil in Sarajevo. In one incident, when a woman mourning the death of her grandchild at a cemetery was wounded, a BBC crew helped the woman get to medical aid. See Joumalists Becoming Part of the Story (CNN television broadcast, Aug. 4,1992 ) (transcript available on LEXIS, Nexis library, Script file). In the other, British reporter Michael Nicholson of the Independent Television News smuggled a nine-year-old orphan out of Sarajevo to safety. While some news officials stationed in Europe condemned this decision as a violation of journalistic ethics, Nicholson stood by his actions: "To be partial politically is wrong. But if you act as any decent person would act, then it is okay." Anna Shen, Natasha's Story: Judgment Call in Sarajevo, ColUM. JouRNAlism Rev., Sept./Oct. 1992, at 22, 22 (quoting Michael Nicholson).

113 Consider the reporting of Thomas Friedman, an Arabic-speaking JewishAmerican who won a Pulitzer Prize for his coverage of the 1982 massacres in the Sabra and Shatila refugee camps in Lebanon. Friedman has written that his emotions drove his reporting:

I took Sabra and Shatila seriously as a blot on Israel and the Jewish people. Afterward, I was boiling with anger-anger which I worked out by reporting with all the skill I could muster on exactly what happened in those camps. 
Certainly not all of the values associated with modern objectivity warrant condemnation. It is laudable for newspapers to insist that journalists fairly represent the views of news subjects and seek out a variety of viewpoints. These practices were alien to the scandal sheets of the early partisan press. With respect to justifying restrictive codes of ethics, however, adherence to such principles is not incompatible with allowing off-duty activism on the part of newspaper employees.

The claim that abstention from outside activity is integral to producing unbiased news accounts does not withstand scrutiny. While prevailing norms may bar an individual journalist from acting on her personal values in a public way, merely prohibiting a reporter from participating in a demonstration will not neutralize a strong personal opinion. This point underscores the real value driving restrictions on outside activity: the desire to appear neutral. ${ }^{114}$ In the midst of the Watergate scandal, for example, editors at Newsweek magazine instructed some reporters to remove anti-Nixon posters from their bulletin boards, "lest nonjournalistic visitors to the magazine get the wrong impression about its objectivity. ${ }^{\text {115 }}$ This instruction implicated concerns about how the magazine would be perceived but apparently had little to do with safeguarding against the possibility of individual political beliefs infecting news content.

Moreover, the logic underlying stringent conflict of interest standards has no limiting principle: every journalist likely has some item or affiliation lurking in her background that could compromise what a newspaper perceives as its independence. As one commentator has pointed out, "[f]or most journalists, total freedom from obligations is unlikely. Journalists are real people who live in families, vote and cheer for the home team."116 It is simply

... One part of me wanted to nail Begin and Sharon-to prove, beyond a shadow of a doubt, that their army had been involved in a massacre in Beirut in the hope that this would help get rid of them. I mistakenly thought that they alone were the true culprits. Yet, another part of me was also looking for alibis . . . something that would prove the Israelis couldn't have known what was happening. Although an "objective" journalist is not supposed to have such emotions, the truth is they made me a better reporter.

THOMAS L. FrIEDMAN, From BEIRUT to JeRUSALEM 165 (1989).

114 This issue is taken up in greater detail in the next section. See infra notes 126 -

41 and accompanying text.

115 HeRBERT J. GANS, Deciding What's News 187-88 (1979).

116 Katherine C. McAdams, Non-Monetary Conflicts of Interest for Newspaper 
impracticable to require purity in the backgrounds of reporters. Although the management at the Washington Post would prefer that staff members not even form opinions on issues, ${ }^{117}$ such efforts to mandate personal neutrality can only prove futile.

Newspaper codes of ethics should reflect that there is no necessary correlation between an individual's private affiliations and activities and the content of her news copy. A considerable body of social-scientific research indicates that '[journalists'] personal political beliefs are irrelevant, or virtually so, to the way they cover[] the news. ${ }^{118}$ In an extended study of the newsmaking process at news organizations between 1968 and 1978, sociologist Herbert Gans found that the professional imperatives reward journalists for reporting news "better and faster" than colleagues at rival news organizations. ${ }^{119}$ Consequently, "[p]ersonal political beliefs are left at home." 120 This priority system shapes coverage of presidential and congressional campaigns and the ongoing quest to break political scandals. ${ }^{121}$

The hierarchical structure of editing also undermines employers' purported concerns about an individual reporter injecting political biases into editorial content. Since a journalist's initial version of a story is usually extensively edited by at least one other person in the course of this process, it is unlikely that elements of personal ideological bias would make their way into the final, published account. ${ }^{122}$ The reporter's own awareness of her potential biases

Journalists, 63 JOURNALISM Q. 700, 700 (1986).

117 See Carol Matlack, Without a Cause, 21 NAT'L J. 2908 (1989) (noting that Leonard Downie, former managing editor and now executive editor of the Post, had expressed this preference).

${ }^{118}$ Herbert J. Gans, Are U.S. Journalists Dangerously Liberal?, COLUM. JOURNALISM REv., Nov./Dec. 1985, at 29, 32.

119 Id.

${ }^{120} \mathrm{Id}$.

121 See LarRy J. Sabato, Feeding Frenzy: How ATtack Journalism Has TRANSFORMED AMERICAN POLmics 91 (1991) (explaining that "the deepest bias most political journalists have is the desire to get to the bottom of a good campaign story").

122 See GANS, supra note 115, at 184; MARTIN LEE \& NORMAN SOlOMON, UNRELIABLE SOURCES 16 (1990) ("Firsthand observations by reporters may have little to do with the final copy."). Access to a variety of news accounts on a given issue provides a further means of protecting editorial integrity. As media critic David Shaw noted,

[n]ow, with 24-hour-a-day Cable News Network (CNN), the increasing influence of the traditional networks, the growth of supplemental news services and the widespread availability of the national editions of the New York Times and Wall Street Journal, editors can check their own reporters' work against many reliable sources. 
may serve as an additional check on accuracy and fairness. The ethic of objectivity encourages journalists to take special precautions to guarantee fair coverage of ideologically adverse newsmakers. ${ }^{123}$ At some news organizations editors have already explored this effect by "assign[ing] writers with known personal values to work on a story in which their values were relevant, which would ensure their bending over backwards to remain detached."124

These factors undermine claims that bias will inevitably flow from personal involvement even where the outside activity does relate to an issue that implicates the reporter's beat. Linda Greenhouse, for example, has been widely praised for her fair and impartial coverage of abortion in spite of her now-clear pro-choice sentiments. ${ }^{125}$ Her off-duty participation in an abortion-rights protest apparently did not affect her ability to produce fair accounts of Supreme Court abortion cases.

\section{Public Relations Value}

Newspaper employers argue that even the appearance of a conflict of interest undermines their ability to hold out their papers as objective, nonpartisan organs. This interest transcends professional values, implicating the symbiotic economics of circulation and advertising. Newspaper publishers may fear that publicity surrounding the private political affiliations of their staffs will alienate readers and, more importantly, advertisers. ${ }^{126}$ These concerns

David Shaw, Instant Consensus: How Media Gives Stories Same 'Spin', L.A. TIMES, Aug. 25,1989 , at $1,33$.

123 See STEPHENS, supra note 29, at 266 (noting that most journalists suppress their individual political beliefs when interviewing people with opposing views). While this self-checking tendency discredits institutional justifications for neutrality requirements, it could have deleterious consequences if a reporter were to allow concerns about the perception of fairness to overwhelm her aggressiveness and judgment.

124 GANS, supra note 115, at 184. Andrew Heyward, executive producer of the CBS news program " 48 Hours," noted this tendency in discussing a decision to allow a producer with AIDS to work on a special on the epidemic: "If anything, my experience has been that when journalists have a passionate interest in a subject, they tend to bend over backward to be particularly judicious and open-minded in their coverage." Victor F. Zonana, In the Eye of AIDS, L.A. TIMES, May 27, 1992, at F1, F8 (quoting Andrew Heyward).

${ }^{125}$ See Shaw, supra note 77. Even the legislative director of the National Right to Life Committee has testified to Greenhouse's fairness, albeit in a backhanded fashion: "Of people who regularly cover abortion issues, whose stories are consistently unbalanced, she would not be on the short list." Saul, supra note 54, at 50 (quoting Douglas Johnson).

${ }_{126}$ There is considerable support for the theory that objectivity itself evolved as 
have spurred ethical guidelines in which, as one commentator put it, "anything that appears to be a conflict is treated just as if it were real conflict." 127

One study that examined the relationship between codes of ethics and actual journalistic conduct suggested that such codes are more important as media tools for shaping public perceptions than as determinants of ethical judgments. ${ }^{128}$ Finding scant evidence that ethical guidelines directly inform news judgments, the study propounded an alternative rationale for the codes:

It may be that the most important "effects" of ethics codes are symbolic, rather than behavioral, in nature. From this point of view, written ethics codes might be seen as attempts to persuade various constituencies (staff members, news sources, advertisers, the public) that a news organization is acting in a professional, accountable manner. The intent may never have been for ethics codes to influence actual journalistic behavior. Rather, . . . codes of ethics may have been intended principally as a defense against charges that the news media are arrogant and unaccountable; essentially, as a public relations tool for the press. ${ }^{129}$

As an integral part of most codes of ethics, objectivity is designed to insulate media employers from charges of ideological bias and to preserve the breadth of their advertising base. ${ }^{130}$

These justifications are deficient in several important respects. First, at least with respect to community affairs, there is evidence to suggest that journalists' distance from the communities they cover actually impairs media credibility. Studies have identified lack of community involvement among journalists as a factor contributing to public alienation toward the press. ${ }^{131}$ These studies contradict

a commercial imperative to satisfy the audience preferences of advertisers. See GANS, supra note 115, at 186 (characterizing objectivity as a "commercial consideration" insofar as it reduces the possibility of alienating readers); STEPHENS, supra note 29, at 262 (indicating that the rise of mass-oriented journalism rendered it economically impractical "to tailor a newspaper for Republicans or Democrats or Progressives"); Baker, supra note 33, at 2131 (suggesting that the rise of objectivity was at least partly caused by commercial considerations).

127 GOODWIN, supra note 84, at 298.

${ }^{128}$ See David Pritchard \& Madelyn Peroni Morgan, Impact of Ethics Codes on Judgments by Journalists: A Natural Experiment, 66 JOURNALISM Q. 934 (1989).

129 Id. at 941.

${ }^{130}$ See SOLEY, supra note 99, at 17 (stating that "the claim of objectivity is primarily a shield against criticism").

131 See Cecilie Gaziano \& Kristin McGrath, Newspaper Credibility and Relationships of Newspaper Journalists to Communities, 64 JouRNALISM Q. 317, 328 (1987). Gaziano \& McGrath's study found that "a significant minority of journalists work in relative 
the media's general claim that service in outside organizations by reporters would threaten institutional integrity. In fact, one newspaper publisher has commented that many papers are suffering because "[t]hey've lost contact with their readers." 132

Second, a system of media ethics that bows to commercial interests may undermine a newspaper's ability to project itself as a truly independent entity. For example, it would be ironic for a newspaper, in the name of preserving its credibility, to fire an employee merely because the employee's private political or social affiliations are distasteful to advertisers. ${ }^{133}$ This kind of employment decision could give rise to a damning indictment of the

isolation from news sources, readers, and supervisors" and that "[l]ack of contact with these groups could contribute to decreased press credibility." Id. The American Society of Newspaper Editors has also found that a newspaper's distance from the community impairs credibility. See id. at 317 . While partisan political activism might not address this problem, many codes of ethics also bar active participation in community affairs, such as service on school boards and other local governing bodies. See, e.g., Harwood, supra note 7, at B6 (describing the ethics code of the Washington Post).

132 Schneider \& Gunther, supra note 45, at 55 (quoting Burlington Standard Press publisher William E. Brannen, who said it was a "terrible mistake" for reporters to refrain from involvement in public affairs). Reporters, too, have suggested the benefits of involvement. For example, one reporter said that "[m]embership in national organizations and receiving their mailings help me to get some perspective, to not be provincial.' BRUCE M. SWAIN, REPORTERs' ETHICs 87 (1978) (quoting St. Paul Pioneer Press reporter Carol Lacey).

Perhaps as a result of American journalism's emphasis on detachment, newspapers appear to have fallen out of touch with their readers. A study commissioned by the American Society of Newspaper Editors found that $46 \%$ of the public agreed with the statement that "the press looks out mainly for rich and powerful people.” AMERICAN SOC. OF NEWSPAPER EDITORS, NEWSPAPER CREDIBILITY: BUILDING READER TRUST 16 (1985) [hereinafter NEWSPAPER CREDIBILITY]. Journalist William Greider argues that newspapers have grown so distant and aloof that they can no longer serve as an effective outlet for the concerns of the communities they serve. See WILlIAM GREIDER, WHO WILL TELL. THE PEOPLE 287-306 (1992). Greider suggests that although reporters at a paper such as the Washington Post are better educated and more expert than any generation of reporters in history, they are unable to fulfill a fundamental ideal of responsible journalism: "The one thing they cannot do is express the honest outrage of a situation. They cannot speak in a human voice that is identifiably 'of the people' whom they are writing about." Id. at 295. This phenomenon, Greider writes, precludes a paper like the Post from undertaking a "crusade" on behalf of underrepresented or exploited interests in the community it serves. See id. at 304.

133 See Peerless Publications, Inc., 231 N.L.R.B. 244, 247-48 (1977) (Fanning, dissenting) (arguing that a newspaper that disciplined an employee based on the concerns of advertisers "would be viewed as either arbitrarily punitive or alternatively as forcing its employees to agree with its advertisers' ideas"). For a discussion of the disposition of the Peerless case on appeal, see infra notes 166-74 and accompanying text. 
paper's editorial autonomy. Yet such a decision would be consistent with the emphasis on appearances that guides current ethical standards.

Third, even as media organizations continue to restrict off-duty activism, there has been an increasing tendency for both print and broadcast journalists to express their opinions in various settings on television. In programs like $A B C$ 's This Week With David Brinkley, journalists who adhere to the rituals of objectivity in their work reveal opinions on a wide range of issues, including topics that they have covered "objectively." 134 Media professionals harbor opinions on a wide range of political and social issues that defy complete suppression. ${ }^{135}$ Yet there is no evidence to suggest that these opinions lead to a loss of credibility or trust in the eyes of audiences. ${ }^{136}$ The same reasoning applies to newspapers that take strong partisan positions on editorial pages while remaining objective in news accounts. ${ }^{137}$

Even as a pure public relations vehicle, codes of ethics are of dubious value. Notwithstanding the existing reign of objectivity, a majority of newspaper readers believe that press reports reflect bias. ${ }^{138}$ It has become a rallying cry among conservatives that media content generally reflects a liberal slant. ${ }^{139}$ Concerns about political exploitation lack resonance because the press has

134 In January 1991, six prominent journalists, appearing on either This Week with David Brinkly or The Donahue Show, gave their personal opinions on the wisdom of going to war against Iraq. Among these journalists was United Press International's Helen Thomas, who maintained that such pronouncements need not inhibit a reporter's ability to "do a fair job." Nicols Fox, Journalists Vote on War: 4 Yes, 2 No, WASH. JOURNALISM REV., Mar. 1991, at 14, 14 (quoting veteran reporter Helen Thomas). At the same time, several journalists appearing on Donahue refused to reveal their opinions for fear of endangering their credibility. See id.

135 See, e.g., Thomas B. Rosenstiel, Reporters on TV: Is Stardom Weakening the Press?, L.A. TIMES, Apr. 26, 1989, $\S 1$, at 1 (analyzing the increasing tendency of journalists to appear as guests on opinion-driven political talk shows).

${ }^{136}$ In fact, awareness of a reporter's perspective may help place a particular news account in context for readers or viewers. See infra note 251 and accompanying text.

${ }^{137}$ See GOODwIN, supra note 84, at 61 (citing publisher John Cowles, Jr., who believes that while news departments should be neutral, " $[$ [p]ublishers should be able to express their views not just through their editorial pages but through their efforts and work in the community").

${ }^{138}$ See NEWSPAPER CREDIBILITY, supra note 132, at 27 (citing a survey which showed that $54 \%$ of respondents believed that ${ }^{\text {" }}[t]$ he personal biases of reporters often show in their news reports").

${ }^{139}$ See LEE \& SolOMON, supra note 122, at 143. Lee and Solomon argue that notwithstanding conservative claims, the notion of a liberal press constitutes cither a myth or an exaggeration. See id. 
already been the subject of manipulative attacks by politicians. ${ }^{140}$ None of this is to suggest that a newspaper committed to balanced reporting should accommodate activism by its staffers where personal affiliations demonstrably interfere with reporting. ${ }^{141}$ Where no such actual conflict exists, however, newspapers should not restrict the expressive activity of their employees.

\section{B. Selective Enforcement and Individual Rights}

Further evidence of the absence of a principled rationale for restrictions on off-duty activism lies in the manner in which such restrictions have been enforced. Given their potential for interference with the personal lives of media employees, restrictive guidelines demand consistent application. Enforcement of ethics codes, however, has proven inconsistent and, at times, downright hypocritical. ${ }^{142}$

An examination of the enforcement of these guidelines should begin with a recognition that few if any reporters are free from any obligations or outside ties, whether they spring from past experience or current activities. ${ }^{143}$ The sweeping language of most codes of ethics promotes a perception that media professionals approach their craft with no affiliations that might constrain their independence. In truth, however, a wide array of journalists carry heavy political or ideological baggage from previous careers and relationships. ${ }^{144}$ The conventions of American political culture

${ }^{140}$ Politicians may seize every opportunity to deflect criticism by focusing attention on the press. In a 1988 interview concerning his involvement in the IranContra affair, for example, then-presidential candidate George Bush warded off the sharp questioning of CBS News anchor Dan Rather by alluding to an episode in which Rather had stormed off the CBS set one evening. See JACK W. GERMOND \& JULES WITCOVER, WHOSE BROAD STRIPES AND BRIGHT STARS? 118-27 (1989). The recent gubernatorial bid in Massachusetts by Boston University President John Silber generated similar press-baiting. See Steve Singer, A Silber Bullet Aimed at the Press, WASH. JOURNALISM REV., Nov. 1990, at 18, 18 (reporting Silber's claim that "I've been running against the press since the beginning of the campaign'").

141 For example, a reporter assigned to cover the Democratic presidential campaign could not well campaign for one of the candidates in the race on her own time (even if the campaign beat left her such time). In fact, the long hours that accompany a demanding beat may preclude off-duty activism by reporters. One reporter who affirmed that "I never ceased to be a citizen when I was a reporter" also said that he never had enough time to engage in extensive outside involvement. SwaIN, supra note 132, at 86 (quoting McCandlish Phillips of the New York Times).

142 See, e.g., supra notes 90-92 and accompanying text (discussing the inconsistency with which one newspaper enforced its ban on community involvement).

143 See supra note 116 and accompanying text.

144 See Charles Trueheart, Trading Places: The 'Insiders' Debate, WASH. Post, Jan. 
have enabled a core group of elites to shuttle back and forth between the three branches of government and the press with relative fluidity and little scrutiny. This revolving-door syndrome has deep historical roots; among its more blatant manifestations was the nineteenth-century congressional practice of hiring journalists to double as secretaries and clerks. ${ }^{145}$ In modern times, the lines remain quite blurred. Today's "objective" outsiders are often former political insiders, according various segments of the press a distinctly establishmentarian bent. ${ }^{146}$

4,1989 , at $\mathrm{D} 1$. The array of media personnel who fall within this category includes news executives, editors, columnists, and reporters. After surveying the media in 1989, Trueheart offered this list as a starting point:

Hodding Carter of PBS' "Inside Story," Bernard Kalb of NBC and James Greenfield of The New York Times (assistant secretaries of state); ABC correspondent John Scali (U.S. ambassador to the United Nations); NBC commentator John Chancellor (Voice of America director); Hendrik Hertzberg of The New Republic (chief speechwriter for Jimmy Carter) ... Jodie Allen, The [Washington] Post's deputy editor of the Outlook section (deputy assistant secretary of labor); Governing magazine editor and former New York Times reporter Eileen Shanahan (assistant secretary of health, education and welfare); The San Diego Union's Gerald Warren (White House deputy press secretary).

Id. at $\mathrm{D} 16$.

145 See RITCHIE, supra note 25, at 4.

${ }^{146}$ This practice may account for the large degree of homogeneity among news sources. The establishment backgrounds of influential reporters "explains why these reporters seek out the views of political leaders, corporate chieftains, and the top brass of the military, but not the views of labor union spokespersons, members of grassroots political organizations, or minorities." See SOLEY, supra note 99, at 143 (citations omitted). This is not to suggest that a political background should preclude a career in journalism. Such experience may provide significant benefits in terms of perspective, contacts, and access to information. See Trueheart, supra note 144, at D16 (noting that editors value the experience, insight, and sophistication of reporters with a government background); see also GERMOND \& WrTCOVER, supra note 140, at 59-60 (suggesting that political reporting benefits from informal contacts between journalists and candidates). NBC News Senior Vice President and Washington bureau chief Timothy Russert, for example, has said that his experience as chief of staff for Senator Daniel Patrick Moynihan has enhanced his ability to ask incisive questions of guests on Meet the Press: "When I'm interviewing someone, I know what exercise they've gone through, what points they're trying to make, what questions they're trying to avoid." Judy Flander, The Insider, Colum.JoURNALISM REV., Sept.-Oct. 1992, at 40,40 (quoting Timothy Russert). But the press needs to be much more sensitive to the impact on its content of having its professionals move back and forth between media enterprises and government positions. The revolving-door tradition likely has a greater impact on media content than most of the types of off-duty outside activity restricted by codes of ethics. The intimate contacts between press and government fostered by this tradition may help explain the media's failure to uncover scandals such as the Iran-Contra affair and the savings and loan debacle. See ROBERT PARRY, FOOLING AMERICA: How WASHINGTON INSIDERS TWIST THE TRUTH AND MANUfaC- 
As part of this phenomenon, newspapers have applied their codes of ethics in a markedly inconsistent fashion. The New York Times may have condemned the private, off-duty participation of its Supreme Court correspondent, but it had no ethical qualms about hiring a former lieutenant general to cover military affairs. ${ }^{147}$ The principal ground for distinguishing these two cases no doubt would be that the general's military activity had ended before he picked up his reporter's notebook. Yet this distinction ignores the possibility that predilections acquired through previous experience continue to inform an individual's news judgment. ${ }^{148}$

The inconsistent application of ethical standards raises the specter of selective enforcement. Membership in unpopular groups or orientations subject to widespread prejudice may be particularly vulnerable under current regimes in which employers can use professional norms as a pretext for discrimination. 149 The severity of the penalty imposed by news organizations for violations of ethical codes may well depend on the cause for which the reporter is working and the public fallout attending the discovery of the

TURE THE CONVENTIONAL WISDOM 12 (1992) (arguing that the media "managed to miss nearly every major scandal of the $\left.1980 \mathrm{~s}^{\prime \prime}\right)$.

${ }^{147}$ See Ex-General to Join the Times, N.Y.TIMES, Sept. 16, 1986, at A21 (announcing that Bernard Trainor, a lieutenant general with almost forty years of experience in the Marine Corps, had joined the Times as its military correspondent); see also LEE \& Solomon, supra note 122, at 110 (suggesting that because the Times's editors were attracted by the former general's experience and access to the Pentagon, they "ignored possible conflicts of interest inherent in Trainor's situation"). Several Times editors have moved in and out of the State Department with surprising frequency. See id. at 110-11 (noting that "[i]t appears that matriculating from The State Department greatly enhances the prospects for getting a job with the Times editorial staff"). In addition, another Times reporter, William Beecher, served as an army reserve captain during his stint as military correspondent for the paper. See SOLEY, supra note 99 , at 144 .

${ }^{148}$ Lee and Solomon charge that Trainor allowed his pro-U.S. military bias to skew his judgment in reporting about the Contras. For instance, in 1987 Trainor reported a major Contra victory over the Sandinista government in Nicaragua based on Contra sources. It was subsequently reported, however, that the claimed victory actually involved the murder of civilians. See LEE \& SOLOMON, supra note 122, at 110 (questioning the Times's disregard of the possibility that "Trainor, a lifelong military man, might be partial to the U.S. military establishment").

A former military official need not be precluded from service as a military correspondent, but more prominent disclosure of his background to readers would have been useful. See infra notes 250-51 and accompanying text.

149 In 1984, Associated Press reporter Garry Moes, a born-again Christian, was taken off a state government beat after he publicized his religious views in an interview with a Christian newspaper. When Moes threatened to sue the Associated Press for one million dollars on religious discrimination grounds, he was put back on the beat. See Schneider \& Gunther, supra note 45, at 56. 
alleged violation. In November 1990, for example, Julie Brienza, a former Supreme Court correspondent for United Press International (UPI), was fired amid complaints by a fundamentalist Christian broadcaster that she had abused her position in writing a freelance piece for a gay publication in Washington. ${ }^{150}$ Although UPI said it dismissed Brienza because she had used the company's resources in doing freelance work, ${ }^{151}$ UPI employees apparently believed the firing was rooted in hostility towards lesbianism. ${ }^{152}$ In a lawsuit against the news agency, Brienza has alleged that the firing was grounded in discrimination based on her sexual orientation. ${ }^{153}$ In a separate incident, in August 1991, the Houston Post fired columnist Juan Palomo after a public controversy over the paper's refusal to publish a column in which Palomo acknowledged that he was a homosexual. ${ }^{154}$

At the same time, accommodation of advocacy of more widely accepted causes reflects a principle that journalist Tom Wicker once termed "safe partisanship"-the notion that "[y]ou're not going to be called an activist and you're not going to be called a journalist engagé if you support the government." ${ }^{\text {155 }}$ This phenomenon facilitated a close relationship between mainstream segments of the American media and the Central Intelligence Agency from the early 1950s to the mid-1970s, with organizations like the New York Times and CBS providing "cover" to CIA operatives. ${ }^{156}$ More recently,

${ }^{150}$ See Ethan Bronner, Gay Reporter, in Suit, Will Say UPI Fired Her Under a Client's Pressure, BOSTON GloBe, Nov. 29, 1990, at 6. Referring to Brienza's dismissal, Wisconsin broadcaster Vic Eliason stated during his radio show that "Christianity has triumphed." Howard Kurtz, Media Notes: Gay Bias Suit at UPI, WASH. PosT, Dec. 1, 1990, at C2 (quoting Vic Eliason).

${ }^{151}$ In the course of reporting a story on religious fundamentalists, Brienza used the UPI phone at the Supreme Court to call Eliason for an interview. See Bronner, supra note 150, at 6; Kurtz, supra note 150, at C2.

152 See John Robinson, Homophobia Claimed in Reporter's Firing, BOSTON GLOBE, May 2, 1990, at 3.

${ }_{153}$ See Michelle E. Klass, Suits: Julie Brienza v. United Press International Inc., et al., LEGAL TIMES, Dec. 31, 1990, at 17.

154 See Howard Kurtz, Newspaper Fires Gay Columnist, WASH. PosT, Aug. 31, 1991, at D1. Palomo was subsequently rehired by the paper. See 51 FACTS ON FILE 704 (1991).

135 AMERICAN SOC'Y OF NEWSPAPER EDITORS, PROBLEMS OF JOURNALISM: PROCEEDINGS OF THE 1972 CONVENTION 177 (1972) (emphasis added).

${ }^{156}$ See Lawrence J. Mitchell, III, Espionage: The Symbiotic Relationship Between the Central Intelligence Agency and the American Press Corps, 11 SUFFOLR TRANSNAT'L L.J. 41, 46-48 (1987). Mitchell explains that "[f]or nearly three decades, the [CIA] . . . enlisted hundreds of journalists to channel information abroad in an effort to mold foreign opinion in support of American foreign policy." Id. at 42 . American 
the bent of safe partisanship was evident in the media's coverage of the Gulf War as newspapers and the networks engaged in unabashed flag-waving and deification of the leaders of the U.S. Armed Forces. ${ }^{157}$ One newspaper editor, expressing the prevailing sentiment among news organizations, approved of the insertion of American flags into her paper, but acknowledged that she would object to the presence on her staff of a reporter "emblazoned in a peace sign." 158

In addition to the uneven application of guidelines with respect to newsroom personnel, the Gulf War example underscores the hypocrisy of publishers who insist on abstinence on the part of staff members while entangling themselves in all sorts of political causes and affiliations. The owners of the press are subject to a wide range of outside influences stemming from interlocking corporate connections and relationships to advertisers. ${ }^{159}$ The likelihood of these conflicts skewing media content is much greater, the consequences for the integrity of the press much more grave. ${ }^{160} \mathrm{~A}$ great many incidents bear out the conclusion that the news is firmly

journalists often exchanged information with the CIA and even undertook special cloak-and-dagger assignments at the behest of the Agency. See LEE \& SOLOMON, supra note 122, at 115 (quoting former CIA deputy director Ray S. Cline, who "called the American news media the 'only unfettered espionage agencies in this country').

${ }^{157}$ Although widely accepted, this practice was criticized by some commentators. See, e.g., Howard Rosenberg, TV's Flags and Yellow Ribbons, L.A. TIMES, Feb. 20, 1991, at A9, A10 (arguing that "we need the journalist armed with skepticism on the Gulf story-not the cheerleader armed with pompons-regardless of the way public opinion is blowing").

${ }^{158}$ Carol J. Castaneda, Patriotic Showings Divide the Media, USA TODAY, Feb. 21, 1991, at 5A (quoting Executive Editor Beverly Kees of the Fresno Bee). The editor of the Patriot, a Kutztown, Pennsylvania paper, was fired in February 1991 after he wrote an editorial criticizing the war against Iraq. See Grant Mahon, Hawk Publisher Bombs Dove Editor, WASH. JOURNALISM REV., Apr. 1991, at 14, 14. This incident betokens the absence of diverse editorial viewpoints on the Gulf War. A survey of the 25 largest U.S. newspapers that was undertaken prior to the outbreak of the War found that only one paper flatly opposed the use of military force against Iraq. See Vincent Carroll, The Scarcity of Anti-War Editorial Voices, WASH. JOURNALISM REv., Jan./Feb. 1991 , at 14, 14.

${ }_{159}$ See generally BAGDIKIAN, supra note 5, at 3-4, 167 (noting the increasing control of the media by multinational corporations as well as continuing publisher restraint over certain subject matter stemming from fear of offending advertisers); LEE \& SOLOMON, supra note 122, at 93-100 (describing editorial compromises and selfcensorship resulting from owner and advertiser pressures).

${ }^{160}$ See LEE \& SOLOMON, supra note 122, at 92 (explaining that ultimately "the media owners and managers ... determine which ideas and which version of the facts shall reach the public"). 
under corporate control, impairing the ability of the press as a check on government conduct. ${ }^{161}$

The uneven enforcement of limitations on outside activities is symptomatic of a larger problem: the standards embodied in current codes of ethics lack a compelling justification. In light of the absence of a persuasive rationale for such restrictions on offduty conduct and the significant costs that they exact, broadsweeping prohibitions should be rescinded by employers. Where there is no evidence to suggest that off-duty conduct will subvert the gathering or presentation of news, media professionals should remain free to engage in outside activity.

\section{LEGAL REMEDIES FOR DISPLACED JOURNALISTS}

Media personnel are on the same footing as other private employees in two important respects. First, absent statutory restrictions or a binding employment contract, journalists are subject to the discretion of their employers under employment-atwill principles. ${ }^{162}$ Second, since the hiring and firing decisions of

161 See generally Baker, supra note 88, at 30-81 (arguing that protection of journalists dismissed by publishers who seek to suppress information of public concern is warranted as a means of bolstering the "checking" function of the press).

162 See, e.g., Martin v. Capital Cities Media, Inc., 511 A.2d 830, 839 (Pa. Super. 1986) (rejecting newspaper employee's claim that employment handbook altered her at-will status). Martin addresses the possibility of using a general public policy exception to the employment-at-will doctrine as a means of protecting newspaper employees from being discharged for engaging in expressive conduct. In Martin, a copy editor for the Times Leader in Wilkes-Barre, Pennsylvania placed an advertisement for her "ice cream-hot dog stand" in a competing paper. The Times Leader's publisher fired the employee after characterizing her conduct as "treason" in light of the stiff competition between the two papers. Among other claims, the copy editor advanced the argument that her discharge was contrary to public policy as embodied in several provisions of the Pennsylvania Constitution that protect the "free communication of thoughts and opinions." Id. at 842 (quoting PA. CoNST. art. I, § 7). The court rejected this claim, holding that "[a]n employer ... has the right to discharge an employee for certain speech which is protected by the Constitution." Id. at 843 . The court noted the "legitimate business reason for the discharge . . . to be found in the employer's right to discharge an employee he perceives to be disloyal." Id.

Cases like Martin certainly do not foreclose the possibility of using a public policy exception to employment-at-will as a means of redress for terminated journalists. Indeed, one commentator has suggested that a wrongful discharge remedy be available to those journalists who are fired "in order to suppress the publication of certain information in the newspaper." See Baker, supra note \$8, at 3. Where a newspaper employer asserts a claim that a discharge is necessary to the operation of its business, however, courts would likely be reluctant to condemn such discharges on general public policy grounds. See also MARR A. ROTHSTEIN ET AL., CASES AND 
media employers do not implicate state action, journalists fired for their off-duty activity cannot invoke the protection of 42 U.S.C. $\S 1983,{ }^{163}$ which allows for causes of action to remedy deprivation of rights only where such deprivation has occurred "under color of state law."164 Consequently, reporters must turn to statutory directives restricting employer discretion and granting employees a voice in the establishment of the terms and conditions of employment.

\section{A. Unionized Settings: Ethical Codes as a Mandatory Subject of Collective Bargaining}

One source of protection for the off-duty freedom of media personnel lies in union bargaining and representation. The Newspaper Guild, a national labor union of newspaper employees, ${ }^{165}$ has been a forceful opponent of overbroad conflict of interest restrictions. A grievance filed by a local chapter of the Guild spawned a federal circuit court decision addressing the issue of ethical restrictions on outside activity. ${ }^{166}$

In 1974, the Pottstown Mercury, a daily newspaper serving approximately 30,000 readers in suburban Philadelphia, unilaterally promulgated a new code of ethics curtailing the outside activities of its employees. ${ }^{167}$ The code drew upon the standards adopted by the Society of Professional Journalists a year earlier. ${ }^{168}$ After the

MATERLALS ON EMPLOYMENT LAW 738-39 (1987) (explaining the employment-at-will doctrine and noting the restrictions on employers' discretion).

16342 U.S.C. § 1983 (1988).

164 See, e.g., Lugar v. Edmonson Oil Co., 457 U.S. 922, 942 (1982) (holding that seizure of disputed property by a private party was state action for purposes of § 1983).

165 The Newspaper Guild currently represents employees at 133 of the 1665 daily newspapers in the United States and Canada. Telephone Interview with David Eisen, Director of Research and Information, Newspaper Guild (Sept. 2, 1992).

${ }^{166}$ See Newspaper Guild, Local 10 v. NLRB, 636 F.2d 550 (D.C. Cir. 1980).

167 See id. at 553 \& $\mathrm{n} .2,554$.

${ }^{168}$ See id. at $555 \&$ n.11, 569-70. The Mercury's Code of Ethics provided that:

Secondary employment, political involvement, holding public office, and service in community organizations should be avoided if it compromises the integrity of newspaper people and their employers. Newspaper people and their employers should conduct their personal lives in a manner which protects them from conflict of interest, real or apparent. Their responsibilities to the public are paramount. That is the nature of their profession.

Id. at 569 . In addition, a general office rule stated that " [e]mployees must so conduct themselves outside of office hours as not to reflect adversely on the newspaper or cause loss of business or patronage." Id. at 571. 
code was released, the paper's publisher began sending warnings and cease-and-desist orders concerning employees' outside activities. The employees' collective bargaining representative, the Newspaper Guild of Greater Philadelphia, filed unfair labor practice charges with the National Labor Relations Board alleging that the newspaper breached its obligation to bargain collectively over the terms and conditions of employment embodied in the ethical code. ${ }^{169}$ The Board concluded that although the newspaper had a duty to bargain about the penalty provisions of the code, it was under no such obligation concerning the code's substantive provisions, which were construed as "a legitimate attempt . . . to protect and preserve the credibility [and quality] of [the] newspaper. ${ }^{\text {170 }}$

In Newspaper Guild v. NLRB, the D.C. Circuit reversed and remanded, directing the Board to distinguish between those substantive components of the code that were mandatory subjects of collective bargaining and those areas appropriately within the bounds of absolute publisher discretion. ${ }^{171}$ The court first indicated that "a news publication must be free to establish without interference, reasonable rules designed to prevent its employees from engaging in activities which may directly compromise their standing as responsible journalists and that of the publication for which they work as a medium of integrity. ${ }^{n 172}$ In light of traditional principles of union labor law, however, the court instructed the Board to balance these management prerogatives with the employees' statutory right to collective bargaining. Acknowledging that it was for the Board in the first instance to strike such a balance, the court suggested that the importance of protecting the "civil and economic rights of employees" necessitates a distinction between overbroad prohibitions on all political and community involvement on the one hand and limits on only such secondary employment as would create an irreconcilable conflict of interest on the other. ${ }^{173}$ On remand, the Board ordered the entire code rescinded on the ground that the employer failed to demonstrate how these unilaterally imposed regulations would serve the newspaper's core functions. ${ }^{174}$

169 See id. at 556.

170 Peerless Publications, Inc., 231 N.L.R.B. 244, $244 \&$ n.3 (1977).

171 See 636 F.2d at 564-65.

172 Id. at 561 .

173 See id. at 563.

174 See Peerless Publications, Inc., 283 N.L.R.B. 334, 336 (1987). The Board explained that ${ }^{~}[t]$ he preservation of editorial integrity does not necessarily dictate a 
The principle that a news organization subject to the National Labor Relations Act (NLRA) has to bargain over codes of ethics restrictions represents a source of power for media employees to protect affirmatively their liberty interests. In fact, the Newspaper Guild has insisted upon specific contractual provisions affirming that staff members retain the right to engage in outside activities. In 1982, for example, a dispute arose under the following provision in a contract between the Guild and the Seattle Times:

1. The employees of the publisher shall be free to engage in activities outside of working hours, subject to the following provisions:

(a) Such activities do not consist of or include services performed for any medium in competition with the publisher. (b) Without permission, no employee shall exploit his/her connection with the publisher in the course of such activities. (c) Such activities are not performed for any noncompetitive employer to the embarrassment of the publisher businesswise. ${ }^{175}$

The Guild filed a grievance when the newspaper, after informing a columnist that he would not be permitted to seek a position on a local water commission board, ${ }^{176}$ released a policy barring news and editorial employees from running for both partisan and nonpartisan public offices. At issue was paragraph (c) of the clause, a potentially broad exception protecting employer prerogatives. Nonetheless, an arbitrator said the exception could not be read to bar "all political involvement by its employees represented by the Guild on the basis that such political involvement automatically creates a 'conflict of interest,' destroys the publisher's 'credibility' with its readers, and is therefore an 'embarrassment' to the publisher. ${ }^{\text {177 }}$ The arbitrator ruled in favor of the Guild, rejecting the paper's absolute ban on bids for elective office. ${ }^{178}$

requirement of employee abstention from political participation or service in community organizations." Id.

175 Clark Newsom, Not All Candidacies for Office Prohibited by Contract Clause, PresstIME, Oct. 1982, at 50, 50 (quoting Seattle Times contract provision).

176 This controversy involving humor columnist John Hinterberger was cited as an example above. See supra notes 87-88 and accompanying text.

177 Newsom, supra note 175, at 50 (quoting the opinion of arbitrator William $H$. Dorsey). The opinion also pointed out that the paper had permitted such activity in the past, allowing one editor to hold the position of the local sewer district commissioner. See id.

${ }^{178}$ See id. 
Contract provisions covering outside activity can thus empower media employees, protecting political participation and free speech that would otherwise be subject to the chilling effect of rigid ethical codes. ${ }^{179}$ Such protection, however, is available to only a limited percentage of newspaper employees. The Newspaper Guild represents the staffs of only 133 of the 1665 daily newspapers in the United States and Canada. ${ }^{180}$ Moreover, since bargaining requirements cannot dictate outcomes, ${ }^{181}$ the standards espoused by employers may prevail even in unionized settings. In that case, employees devoted to unpopular causes would remain vulnerable to disparate enforcement of majoritarian norms. And in any case none of this bargaining protection would be available to editors, who fall within the statutory classification of supervisors and therefore are not covered by the NLRA. ${ }^{182}$

A more defensive approach in a unionized setting would be to rely on language in collective bargaining agreements providing that members of the bargaining unit be fired for "just cause" only. ${ }^{183}$ Approximately eighty percent of collective bargaining agreements contain this kind of restriction on an employer's firing discretion. ${ }^{184}$ This protection too, however, only goes so far. In the context of firings for violations of ethical guidelines, it is unclear

179 In 1987, the Guild filed a grievance under an agreement with the Seattle PastIntelligencer, which provided that "[a]ny employee is free to engage in outside activities . . provided such endeavor is not in direct competition with the publisher." Arbiter Upholds Union in Dispute over "Outside Activities," PressTIME, Sept. 1987, at 62, 62 (quoting contract provision). The newspaper sought to impose a requirement that staff members consult their supervisors before taking on any assignments for "any outside media." See id. Arbitrator Michael $\mathrm{H}$. Beck held that this rule violated the outside activity clause because "the employer has effectively attempted to impose an additional exception to the freedom of employees to engage in outside activity." Id.

${ }^{180}$ See Telephone Interview with David Eisen, supra note 165.

181 See Newspaper Guild, Local 10 v. NLRB, 636 F.2d 550, 561 n.35 (D.C. Cir. 1980) ("To be sure, a requirement that the employer must bargain does not necessarily mean that he must reach agreement.") (citation omitted). At the same time, the classification of an issue as a mandatory subject of collective bargaining authorizes the employees to strike should bargaining on that issue result in an impasse. See id.

182 See Wichita Eagle \& Beacon Publishing Co. v. NLRB, 480 F.2d 52, 55-56 (10th Cir. 1973) (holding that an editorial page writer was not an employee within the meaning of the NLRA), cert. denied, 416 U.S. 982 (1974).

183 See Mark T. Carroll, Protecting Private Employees' Freedom of Political Speech, 18 HARV.J. ON LEGIS. 35, 62-63 (1981) (providing examples of "just cause" clauses found in collective bargaining agreements).

184 See id. at 68 . 
whether arbitrators will be receptive to claims that outside activity can be reconciled with the newspaper's interests.

In the McCarthy era, for example, news organizations fired employees for alleged Communist affiliations and then justified the firing with reference to objectivity and credibility. ${ }^{185}$ Arbitrators tended to uphold the discharges on " $[$ t]he theory . . . that newspapers, which have a great responsibility to the public to present objective news, untainted by Communist propaganda, are justified in requiring absolute certainty in their employees' willingness to present unslanted news. ${ }^{186}$ In the case of one reporter fired for refusing to testify before the House Un-American Activities Committee, an arbitrator held in favor of the paper because "a newspaper in particular can reasonably require certainty as to the technique and approach to reporting from its employees." 187 This pattern of deference, flowing in part from the notion that a reporter's off-duty speech "follows him into the workplace," 188 can also be attributed to the general hysteria surrounding charges of Communism in the 1950s. ${ }^{189}$

Modern arbitrators have demanded a higher threshold of employer justification for discharges based on off-duty conduct. In 1983, for example, an arbitrator ordered the reinstatement of Knoxville News-Sentinel reporter Jacqueline B. McClary, who was dismissed for her election to the Alcoa, Tennessee school

185 See id. at 73. The conduct of the New York Times during the McCarthy era is noteworthy in this regard: "[The Times] penalized employees who were noncooperative at congressional hearings and invoked the First Amendment by reducing their editorial responsibilities and prospects for advancement; they fired those who took the Fifth Amendment." NAVASKY, supra note 112, at 58.

${ }^{186}$ Carroll, supra note 183, at 73 n.195 (citations omitted).

${ }^{187}$ Hearst Publishing Co., 30 Lab. Arb. Rep. (BNA) 642, 645 (1958) (Schedler, Arb.), quoted in Carroll, supra note 183, at 73; see also New York Times Co., 26 Lab. Arb. Rep. (BNA) 609,611 (1956) (Corsi, Arb.) (holding that the Times had good cause to dismiss a foreign desk copyreader who acknowledged past membership in the Communist party); United Press Ass'n, 22 Lab. Arb. Rep. (BNA) 679, 683 (1954) (Spiegelberg, Arb.) (finding that United Press would have been justified in discharging reporter who refused to testify before Un-American Activities Committee had it specified concern that customers would infer bias); Los Angeles Daily News, 19 Lab. Arb. Rep. (BNA) 39, 40 (1952) (Dodd, Arb.) (with two dissents, upholding discharge of two editorial writers who refused to deny charges of Communist affiliation).

${ }^{188}$ Carroll, supra note 183 , at 76 \&c n.211.

189 One arbitrator, in upholding the discharge of a New York Daily Mirror rewrite man for his refusal to testify before the Senate Internal Security Subcommittee, explained that "[i]n the year of Our Lord 1956, Communism is a major menace to the free world, to our democratic way of life and to the private enterprise system." New York Mirror, 27 Lab. Arb. Rep. (BNA) 548, 551 (1956) (Turkus, Arb.). 
board. ${ }^{190}$ The arbitrator found that ${ }^{~}[\mathrm{t}] \mathrm{he}$ expression of political beliefs by activities, such as running for office of School Board Director, involves a person's civil rights and cannot be restricted by an Employer except for some proven compelling reason." 191 Although the arbitrator assumed for the purposes of her decision that objectivity was a legitimate employer interest, she found the newspaper's naked assertion that McClary's service endangered its objectivity inadequate. Since McClary never reported on events in Alcoa, the newspaper could present no "credible evidence which would support the ... assertion that Mrs. McClary's election to office would be detrimental to its perceived objectivity. ${ }^{192}$ The decision to reinstate McClary also rested on the ground that the company had not applied its code of ethics in a uniform manner, allowing its editor and other staff members to participate in similar public affairs activity. ${ }^{193}$ This rather exacting analysis of the justifications for McClary's discharge suggests that union arbitrations may provide meaningful protection for the civil and political activity of journalists.

\section{B. Statutory Prohibitions on Political Discrimination}

Many states have passed statutes curtailing the ability of employers to punish their employees for their political activity. ${ }^{194}$ These exceptions to the employment-at-will doctrine vary significantly from state to state, with only a handful creating private civil actions on behalf of employees. ${ }^{195}$ Still, the principles underlying these statutes suggest their potential as a mechanism to empower media professionals who would otherwise continue to be chilled from engaging in political activity. ${ }^{196}$

190 See Knoxville Newspaper Guild, Local 376 v. The Knoxville News-Sentinel Co., A.A.A. No. 3030006983 (June 10, 1983) (Duff, Arb.); see also supra notes 89-92 and accompanying text (discussing the newspaper's justification for the dismissal).

191 Knoxville Newspaper Guild, A.A.A. No. 30300069 83, at 20.

192 Id. at 21.

193 See id. at 15-17.

194 See, e.g., CONN. GEN. STAT. ANN. \$ 2-3a (West 1987) (prohibiting employers from discriminating against individuals who seek election to the state general assembly); infra note 200 (discussing Louisiana's statute). See generally Carroll, supra note 183, at 58 (stating that "[a]t least thirty-seven states and Puerto Rico have statutes protecting in some way the political activities or opinions of employees").

195 See Carroll, supra note 183, at 59-60 (explaining that five states have enacted statutes authorizing civil actions for private deprivations of political rights by employers, while other states provide for criminal fines where such violations have occurred).

${ }^{196}$ In one recent example, a Connecticut statute prohibiting employers from 
The prospect of journalists asserting causes of action against their newspapers in this regard derives from broadly worded statutes passed in states such as Louisiana, California, and Connecticut. Louisiana, for example, provides that "no employer . . . shall make, adopt, or enforce any rule, regulation, or policy forbidding or preventing any of his employees from engaging or participating in politics."197 California prohibits employers from adopting policies "tending to control or direct the political activities or affiliations of employees." 198 Connecticut frames the rights protected more broadly, restricting the latitude employers have in taking retributive measures "on account of the exercise by ... employee[s] of rights guaranteed by the first amendment [sic]. ${ }^{199}$

A comparison of these statutes suggests that several components of statutory protections for political activity will determine how useful they are to journalists fired for their outside activity. The first component is the nature of the activity protected. Where the vague term "politics" or "political activity" is used, judicial construction of the language will determine the scope of the right. The California Supreme Court, for example, initially read section 1101 of the California Labor Code to extend only to "activities ... related to or connected with the orderly conduct of government and the peaceful organization, regulation and administration of the government. ${ }^{n 200}$ In recent years, however, the court has widened the range of activity protected by the statute, finding that "the term "political activity" connotes the espousal of a candidate or a cause, and some degree of action to promote the acceptance thereof by other persons." 201 Activism on behalf of homosexual rights was held sufficient to trigger the protection of the statute. ${ }^{202}$ Presumably, then, an editorial employee fired for private, off-duty support

discriminating against individuals who seek election to the state general assembly, see CONN. GEN. STAT. ANN. § 2-3a (West 1987), enabled a managing editor to retain his position after announcing his candidacy for the Connecticut Senate in May 1992. See Rolf Rykken, The Editorial Candidate, Presstime, Oct. 1992, at 6, 6. Chris Powell, managing editor of the Journal Inquirer in Manchester, was assigned non-news related responsibilities during his campaign. See id.

197 LA. REV. STAT. ANN. § 23:961 (West 1985).

198 Cal. Lab. Code $\S 1101$ (West 1989).

199 Conn. Gen. STAT. ANN. \$ 31-51q (West 1987).

${ }^{200}$ Lockheed Aircraft Corp. v. Superior Court, 171 P.2d 21, 24 (Cal. 1946).

201 Gay Law Students Ass'n v. Pacific Tel. \& Tel. Co., 595 P.2d 592, 610 (Cal. 1979) (alteration in original) (quoting Mallard v. Boring, 182 Cal. App. 2d 390, 395 (Dist. Ct. App. 1960)).

202 See id. at 611. 
of a political candidate or social cause would have legal recourse against a newspaper under California's section 1101.

Certain statutes, however, arm the employer with a defense or exemption in certain situations. Connecticut, for example, denies protection where the activity "substantially or materially interfere[s] with the employee's bona fide job performance or the working relationship between the employee and the employer. ${ }^{\text {203 }}$ Such an exemption would likely render the statute inapplicable to the situation at issue here, for a media employer could assert that abstention from outside activity has been widely endorsed as a means of preserving credibility. Other state courts, however, have refused to fashion such a defense where the statute itself is silent as to possible employer defenses. For example, in upholding an action against a corporation brought by a former employee fired for seeking election to the city council, a Louisiana appellate court rejected the employer's claim of economic necessity even after acknowledging that the justification was a "real one."204

Of course, the policy underlying passage of these statutes does not address the special nature of the role of journalists nor the peculiar needs of media enterprises. Whether the application of these general statutes to newspaper employers can be reconciled with First Amendment jurisprudence is a question taken up in Part IV.D. Moreover, since there apparently has been no litigation involving journalists under these statutes, the suggestion that the provisions be used to generate causes of action for terminated reporters remains somewhat speculative. Still, if political discrimination provisions were expanded and enforced, ${ }^{205}$ this category of employment remedies could well serve the interests of any employees, including journalists, who get fired for engaging in outside activity.

203 CONN. GEN. STAT. ANN. \$ 31-51q (West 1987).

${ }_{204}$ See Davis v. Louisiana Computing Corp., 394 So. 2d 678, 679 (La. Ct. App.), cert. denied, 400 So. $2 d 668$ (La. 1981). In Davis, the court sympathized with the corporate employer's argument that the employee's candidacy would antagonize officials in the community upon whom the employer depended for his business. Nevertheless, the court concluded that there was "no exemption from the legislative purpose because of the nature of the employer's business." Id.

205 See, e.g., Carroll, supra note 183, at 78-80 (proposing a statute designed to "accommodate both free-speech interests and economic-efficiency interests in the employee/employer relationship"). 


\section{Title VII and the Duty to 'Reasonably Accommodate' Abortion-Related Advocacy by Media Personnel}

The incidents described in part II of this Comment reveal the wide sweep of newspaper prohibitions on off-duty activities and affiliations. When the issue at stake is abortion, these affiliations may have religious underpinnings. ${ }^{206}$ Pro-life activists often cast their opposition in religious terms and may organize their activities around church groups. ${ }^{207}$ Thus an employee whose beliefs regarding abortion come into conflict with her work conditions or performance may seek protection under Title VII of the Civil Rights Act of 1964, which prohibits discrimination in employment based on an employee's religion. ${ }^{208}$

Title VII provides that it is illegal for any employer "to fail or refuse to hire or to discharge any individual ... . with respect to his compensation, terms, conditions, or privileges of employment, because of such individual's ... religion. ${ }^{\text {209 }}$ The statute was amended in 1972 to include the following definition of religion: "The term 'religion' includes all aspects of religious observance and practice, as well as belief, unless an employer demonstrates that he is unable to reasonably accommodate to an employee's or prospective employee's religious observance or practice without undue hardship on the conduct of the employer's business."210 Taken together, these two provisions suggest that religious discrimination can derive from an employer's failure to reasonably accommodate an employee's religious beliefs and observances. ${ }^{211}$

The Supreme Court, however, has construed this obligation quite narrowly. ${ }^{212}$ The crux of the Court's interpretation of the

206 See Kent Greenawalt, Religious Convictions and Political Choice 120 (1988) (stating that "[i]nduced abortion is the most controversial social issue as to which religious views figure prominently"); Weston, supra note 68, at 12 (comparing positions on the permissibility of abortion among the world's major religions and their subdivisions).

207 For an example, see supra notes $72-76$ and accompanying text.

208 See 42 U.S.C. § $2000 \mathrm{e}-2(\mathrm{a})(1)$ (1988).

209 Id.

210 Title VII of the Civil Rights Act of $1964, \S 701$ (j), 42 U.S.C. $\$ 2000 \mathrm{e}(\mathrm{j})$ (1988).

211 See Ansonia Bd. of Educ. v. Philbrook, 479 U.S. 60, 69 (1986) (holding that an employer that offers a "reasonable accommodation" of the employee's religious interests has met its obligation under \$ 701(j)); Trans World Airlines, Inc. v. Hardison, 432 U.S. 63, 77 (1977) (holding that Title VII requires only "reasonable efforts" to accommodate an employee's religious needs).

212 See Peter Zablotsky, Afler the Fall: The Employer's Duty to Accommodate Employee Religious Practices Under Title VII After Ansonia Board of Education v. Philbrook, 50 
reasonable accommodation requirement lies in its construction of the term "undue hardship." An employer is excused from the duty to accommodate religious practices where such accommodation would result in "more than a de minimis cost" to her business. ${ }^{213}$ Moreover, an employer's proposed accommodation need not be the most reasonable with respect to the religious interests of the employee. ${ }^{214}$ “[T] he statute directs that any reasonable accommodation by the employer is sufficient to meet its accommodation obligation. ${ }^{215}$

In light of this narrow construction, a newsroom professional pursuing a religious discrimination claim against a newspaper based on her abortion advocacy faces a difficult task. Consider the case of a reporter fired for active membership in a pro-life group affiliated with her church. In order to establish a prima facie case of religious discrimination, the individual would have to prove that 1) she had a bona fide belief that her religiously grounded convictions concerning abortion rendered her unable to comply with the restrictions of a newspaper's code of ethics, and 2) she was fired for her noncompliance. ${ }^{216}$ Under the "de minimis" standard constructed by the Court, however, a newspaper could likely meet the reasonable accommodation requirement by advancing the argument that the presence of an outspoken pro-life advocate on its editorial staff would exact significant, that is, unreasonable, costs in terms of the paper's editorial discretion. ${ }^{217}$

In spite of this limitation, there remains one scenario that could yield success for a discharged journalist in the case described above: where a newspaper is enforcing its policy selectively, allowing certain outside activities but refusing to accommodate abortion activism. The Court has suggested that employers violate the commands of Title VII when they make special arrangements for all the needs of employees "except religious ones . . . . Such an arrangement would display a discrimination against religious practices that

U. PITT. L. REV. 513, 573 (1989) (concluding that Ansonia represented a move to a more easily satisfied reasonable accommodation standard).

${ }^{213}$ See Hardison, 432 U.S. at 84 (emphasis omitted).

214 See Ansonia, 479 U.S. at 68.

215 Id.

${ }^{216}$ See Laura S. Underkuffler, "Discrimination" on the Basis of Religion: An Examination of Attempted Value Neutrality in Employment, 30 WM. \& MARY L. REV. 581, 593 n.50 (1989) (laying out the elements of a prima facie case under Title VII).

217 The constitutional protection afforded editorial discretion will be discussed in Part IV.D infra. 
is the antithesis of reasonableness." 218 Using similar reasoning, a court might hold against a newspaper that tolerated membership in the Sierra Club by an environmental reporter but refused to accommodate a business editor's affiliation with Citizens for Life. This category of claims, however, necessarily rests on factual inquiries into the personal affiliations and activities of other employees, which might prove impracticable if they are not publicly known.

\section{Constitutional Barriers?: Codes of Ethics and Editorial Discretion}

Parts IV.A-.C suggested several possible sources of legal redress for journalists who are discharged pursuant to newspapers' conflict of interest policies. As noted, these remedies have limitations on their own terms. Independent of these inadequacies, however, the special protection afforded to the press by the First Amendment raises the question whether employment law remedies can ever be constitutionally applied to the actions of newspapers in enforcing their codes of ethics.

The remedies suggested above derive from generally applicable civil statutes. This factor is significant as a threshold matter because the Supreme Court has repeatedly held that the First Amendment does not necessarily insulate the press against enforcement of civil statutes of general applicability. This principle grew out of a case involving a discharge of an Associated Press editorial employee who had engaged in union activity. ${ }^{219}$ When the union brought unfair labor practice charges against Associated Press under the NLRA, Associated Press invoked the First Amendment in an effort to preclude inquiry into the reason for the discharge. ${ }^{220}$ The Supreme Court rejected this argument, holding that " $[t]$ he publisher of a newspaper has no special immunity from the application of general laws." 221 The case, however, might have come out differently had Associated Press asserted that forbidding a news agency to fire an employee for union advocacy infringed upon "its policy

218 Ansonia, 479 U.S. at 71.

219 See Associated Press v. NLRB, 301 U.S. 103, 130 (1937) (holding that the employee's discharge was prohibited under the NLRA and that such prohibition was not an unconstitutional abridgement of freedom of the press).

220 See id. at $130-32$.

221 Id. at 132. 
of impartiality." ${ }^{222}$ Since Associated Press instead argued broadly that "any regulation protective of union activities . . . is necessarily an invalid invasion of the freedom of the press, ${ }^{223}$ the Court expressly declined to address the merits of the narrower claim that application of the NLRA in this instance would have "subverted" the organization's standard of objectivity. ${ }^{224}$

The Supreme Court has reaffirmed the "laws of general applicability" principle in the contexts of antitrust law, ${ }^{225}$ the Fair Labor Standards Act, ${ }^{226}$ a city ordinance governing discriminatory advertising, ${ }^{227}$ amenability to subpoenas, ${ }^{228}$ and promissory estoppel claims. ${ }^{229}$ These cases stand for the proposition that "the First Amendment does not invalidate every incidental burdening of the press that may result from the enforcement of civil or criminal statutes of general applicability. 230

At the same time, certain kinds of laws that are facially neutral in application may nonetheless implicate First Amendment

222 Id.

223 Id. at 131.

224 See id. at 132.

${ }^{225}$ See Associated Press v. United States, 326 U.S. 1, 7 (1945) (holding that publishers are equally subject to antitrust laws).

${ }^{226}$ See Oklahoma Press Publishing Co. v. Walling, 327 U.S. 186, 193 (1946) (holding that application of the Fair Labor Standards Act in publishing contexts does not violate the First Amendment).

227 See Pittsburgh Press Co. v. Pittsburgh Comm'n on Human Relations, 413 U.S. 376, 391 (1973) (holding that an ordinance prohibiting sex-designated advertising for non-exempt job opportunities did not violate a newspaper's First Amendment rights).

${ }^{228}$ See Branzburg v. Hayes, 408 U.S. 665, 690 (1972) (holding that the First Amendment does not provide reporters with special protection or relief from the obligation to respond to grand jury subpoenas).

229 See Cohen v. Cowles Media Co., 111 S. Ct. 2513, 2515 (1991) (holding that the First Amendment does not bar promissory estoppel claims).

${ }^{230}$ Branzburg, 408 U.S. at 682 . The scope of the "laws of general applicability" principle first articulated in Associated Press $v$. NLRB remains somewhat murky in light of the Court's subsequent decision in Cohen. In that case, the Court was divided on the question of whether Minnesota's doctrine of promissory estoppel could constitutionally be applied to a reporter's broken promise of confidentiality to a source. Writing for a 5-4 majority, Justice White concluded that the promissory estoppel action could be maintained against the reporter's newspaper insofar as it grew out of a "generally applicable law" that placed no special burdens on the press. Justice White distinguished Hustler Magazine Inc. v. Falwell, 485 U.S. 46 (1988), on the ground that unlike the plaintiff in that case, the source in Cohen was not "seeking damages for injury to his reputation or his state of mind." Cohen, $111 \mathrm{~S}$. Ct. at 2519. The dissenters argued forcefully that this distinction had no logical or precedential foundation given that "the publication of important political speech is the claimed violation.” Id. at 2521 (Blackmun, J., dissenting). 
protections where "the content of publication" is at issue. ${ }^{231}$ The common law tort of intentional infliction of emotional distress, for example, must be analyzed in accord with the First Amendment where the source of the alleged infliction lies in editorial content. ${ }^{232}$ In evaluating any generally applicable law, it is important therefore to identify the nature of the media entity's First Amendment interest susceptible to abridgement.

In causes of action brought by former employees discharged for non-job-related activities, the interest at stake is a newspaper's right to enforce its code of ethics against its employees. Since ethical standards are generally considered part of editorial policy, a newspaper would appear to have a compelling First Amendment defense to such actions. Upon closer scrutiny, however, actions to protect media employees from the overbroad sweep of conflict of interest guidelines are distinguishable from regulations that strike at the heart of editorial content.

The Supreme Court has framed the press's right to editorial independence in absolutist terms. In Miami Herald Publishing Co. v. Tornillo, ${ }^{233}$ a case striking down Florida's "right of reply statute, ${ }^{234}$ the Court indicated that

[t]he choice of material to go into a newspaper, and the decisions made as to limitations on the size and content of the paper ... constitute the exercise of editorial control and judgment. It has yet to be demonstrated how governmental regulation of this crucial process can be exercised consistent with First Amendment guarantees of a free press as they have evolved to this time..$^{235}$

The Miami Herald's sweeping language suggests that newspapers enjoy considerable immunity from efforts to regulate any action by a newspaper that can properly be characterized as part of the "function of editors." 236

The difficulty in reconciling employment law remedies with this constitutional principle was evident in Passaic Daily News $v$.

231 See Cohen, 111 S. Ct. at 2522 (Souter, J., dissenting).

232 See Hustler Magazine, 485 U.S. at 56 (holding that unless false statements are published with "actual malice," public figures and officials are prohibited from recovering damages for intentional infliction of emotional distress).

233418 U.S. 241 (1974).

254 The statute provided that newspapers that attacked the "personal character or official record" of a political candidate were obliged to accord the candidate free and equal space to respond to the charges. See id. at 244.

233 Id. at 258.

236 See id. 
$N L R B,{ }^{237}$ a D.C. Circuit case involving the discharge of a columnist who had engaged in union organizing activity. The court found substantial evidence to support the conclusion that the columnist's firing was rooted in antiunion animus in violation of the NLRA. ${ }^{238}$ At the same time, the court held that Miami Herald foreclosed enforcement of that part of the NLRB's order requiring that the paper resume publication of the employee's column. ${ }^{239}$ Such an order, the court argued, would be tantamount to "an 'express or implied command that the press publish what it prefers to withhold." 240

First Amendment cases like Miami Herald and Passaic Daily News establish an obstacle to causes of action that might have the effect of regulating editorial content. The issue presented here, however, is farther removed from the realm of editorial discretion than an order requiring publication of material. The off-duty activities of media professionals do not implicate editorial content where offduty activity has no relation to job performance. In these circumstances, a newspaper should not be able to cloak its employment decisions in constitutional rhetoric. Concerns about avoiding the mere "appearance" of a conflict of interest should not guide First Amendment jurisprudence.

Indeed, the D.C. Circuit has recognized that, in the context of restrictions on individual rights, the scope of immunity for editorial processes is not boundless. ${ }^{241}$ The court argued that "[ $\left.t\right]$ he degree of control which may be exercised by a publication in this regard is not open-ended, but must be narrowly tailored to the protection of the core purposes of the enterprise. ${ }^{242}$ Unless a newspaper can demonstrate that the activity in question has colored or otherwise impaired a reporter's work product, journalists should enjoy generally available statutory remedies against their employer. ${ }^{243}$

\footnotetext{
237736 F.2d 1543 (D.C. Cir. 1984).

238 See id. at 1549.

239 See id. at 1557-59.

${ }^{240} \mathrm{Id}$. at 1557 (quoting Branzburg v. Hayes, 408 U.S. 665, 681 (1972)).

241 See Newspaper Guild, Local 10 v. NLRB, 636 F.2d 550 (D.C. Cir. 1980).

242 Id. at 561 n.36.

243 In a seminar discussion at the University of Pennsylvania Law School, Prof. C. Edwin Baker suggested that, carried to its logical extreme, the principle that the law can be constitutionally applied to protect the activity of journalists from the sweep of objectivity-driven ethical codes would authorize interference with efforts by a partisan paper to retain only those employees who share the paper's partisan affiliations. See C. Edwin Baker, Mass Media Policy Seminar, in Philadelphia (November 1991). This
} 


\section{BEYOND DETACHMENT: A NEW DIRECTION FOR JOURNALISM}

The need to protect the individual freedom of journalists animates this Comment's principal argument against overbroad restrictions on outside activity. ${ }^{244}$ Beyond this concern for individual liberty, however, a movement towards greater individual autonomy for journalists both on and off the job could benefit the press on an institutional level. This assertion leads directly to the longstanding normative debate surrounding the appropriate nature of editorial content. A well-settled and valuable body of First Amendment jurisprudence dictates that such norms must result from the unfettered, private editorial decisions of newspapers. ${ }^{245}$ In light of this precedent, this section considers the implications of

point is well-taken. Nonetheless, one proposed scheme for protecting the free speech of private employees suggests grounds for distinction. Under this scheme, a partisan paper would qualify as an "amplifying organization" in which the employer's "First Amendment rights are proxies for the expressive and associational rights of its members." Note, Free Speech, the Private Employee, and State Constitutions, 91 YALE L.J. 522,538 (1982). The partisan publisher's free speech and associational rights would insulate her from the application of statutes or standards that seek to vindicate the First Amendment rights of private employees. At the same time, "[n]ewspapers that exist primarily to disseminate ideas but not ideology would ... fail the test" and therefore be subject to enforcement of the standards. See id. at 544 . An interesting application of this distinction can be found in Feldstein v. Christian Science Monitor, 555 F. Supp. 974 (D. Mass. 1983), where a religious discrimination suit was brought by a Jewish job applicant against the Christian Science Monitor. The court held that publication of the Monitor was primarily a "religious activity" of the First Church of Christ, Scientist, enabling the Monitor to "apply a test of religious affiliation to candidates for employment." Id. at 979.

Along the same lines, a partisan paper would have a strong argument that its preferred political affiliation amounts to a critical qualification for the performance of the task at hand; thus, for example, a staunch conservative activist would have difficulty finding harmonious employment at The Nation. In contrast, abstention from off-duty involvement in community affairs and political involvement is not a necessary requirement for reporters working toward the ideal of objectivity.

The context of partisan papers also provides an interesting counterpoint to the statutory remedies discussed here. In Europe, where papers generally break down along partisan lines, some countries have enacted "conscience clause" legislation providing protection to journalists where their newspaper undergoes significant changes in political perspective such that it would be morally offensive to continue working there. In these situations, journalists can resign immediately but still receive full compensatory benefits. France, for example, accords such privileges in the event of "'an appreciable change in the character or trend of the newspaper or periodical, if this change places the employee in a situation likely to cast a slur upon his honour or reputation or to affect his moral interests in general." See G. BOHËRE, PROFESSION: JOURNALIST 68 (1984) (quoting and explaining a French law of March 29, 1935, article $30 \mathrm{~d}$, First Book of the Labour Code).

244 See supra notes $45-93$ and accompanying text.

245 See supra notes $233-40$ and accompanying text. 
greater activism by reporters in the normative context of the standards that should govern American journalism.

\section{A. Disclosure: A More Honest Approach to Conflicts}

If newspapers were to accommodate greater activism by individual newsroom personnel, however, how can the institutional needs of the papers be satisfied? The subtle infiltration of bias into the news reports of an avowedly unaffiliated observer may constitute a greater risk to objectivity than the presence of a known advocate on an editorial staff. ${ }^{246}$ In the tradition of disclosure as a "disinfectant[],"247 reporters should be free to engage in activism on their own time and then reveal relevant biases or affiliations up front, to their editor and perhaps even to their audience. Such disclosure would alert editors concerned with neutrality to the possibility of meaningful conflicts of interest. On some occasions, journalists themselves have taken the initiative and approached their editors about certain assignments out of concern over their ability to report dispassionately on the topic. ${ }^{248}$ When reporters have prohibitively strong political or personal feelings, one option newspaper editors have is to reassign staff members to different stories.

In circumstances where a reporter's background or experience directly implicates the subject of her story, disclosure in the medium itself would enable readers to better evaluate the source of their own information. ${ }^{249}$ Such disclosure would not be unprecedent-

216 Even Walter Lippmann, who is generally considered to be the godfather of objectivity, once became a furtive participant in political affairs when he contributed to a foreign policy address by a United States senator and then subsequently hailed the address in his columns without disclosing his involvement. See RITCHI, supra note 25, at 1 . A modern analogue of that incident occurred in 1980 when columnist George Will lauded the debate performance of presidential candidate Ronald Reagan without revealing that he had coached Reagan prior to the debate. See GolDSTEIN, supra note 65 , at 79 .

247 See LOUIS BRANDEIS, OTHER PEOPLE'S MONEY 62 (Richard M. Abrams ed., Harper Torchbook 1967) (1914). In discussing the importance of publicizing the financial concentrations of trusts, Brandeis wrote that "[s]unlight is said to be the best of disinfectants; electric light the most efficient policeman." Id.

218 See Shaw, supra note 77, at A23 (reporting the experience of one Los Angeles Times reporter, Patt Morrison, who was not given assignments related to abortion after she expressed her concerns over her beliefs to her editors); see also GANS, supra note 115, at 184 (noting that the news media generally attracts people who keep their values separate from their work).

249 This kind of disclosure can be effected in at least two possible ways. First, the disclosure can actually be inserted somewhere in the text as a part of the story. In 
ed. In 1978, an Idaho newspaper disclosed to its readership a detailed list of the affiliations, political and otherwise, of all its staffers and its publisher. ${ }^{250}$ This kind of unlimited public disclosure may go farther than necessary and thereby needlessly endanger the privacy interests of journalists whose outside activities are unrelated to the subjects about which they write. Nonetheless, when appropriately tailored to a particular set of facts, disclosure is valuable insofar as "[i]f one knows the biases of a reporter, it is possible to control for them in interpreting his or her accounts of events. ${ }^{251}$ This approach represents a more honest method of dealing with possible conflicts of interest than the assertions of purity that currently pervade the debate on journalistic ethics. ${ }^{252}$

\section{B. Citizens on the Job}

Current media practices construct a somewhat artificial dichotomy between a reporter's beliefs as a private citizen and her work as a member of the press. Part III of this Comment suggested that off-duty activism can be successfully separated from media content given prevailing professional imperatives and hierarchies. Suppose, however, that news publications encouraged journalists to act on their concerns as citizens and members of their community. In tandem with a policy of disclosing any interpretive perspectives or biases to audiences, a movement in this direction could produce more socially desirable journalism.

this way, a reporter can inform readers when she is drawing directly on her experience. Second, the disclosure can be included as part of the identification of the author, either under the by-line or at the end of the story.

250 See Charles W. Bailey, Conflicts of Interest: A Matter of Journalistic Ethics, NIEMAN REP., Autumn 1984, at 40, 43.

251 BENNETT, supra note 32, at 78. Readers may well feel betrayed when they learn about relevant aspects of the writer's background that were not disclosed at the time of publication. Consider the fallout from the revelation that, at the same time he was defending Supreme Court nominee Clarence Thomas in a column, Washington Post columnist Juan Williams was himself the target of a sexual harassment probe at the paper. See Howard Kurtz, Writer of Thomas Column Focus of Allegations at POST, WASH. PosT, Oct. 15, 1991, at A4.

232 Several states have considered but ultimately rejected bills mandating forms of disclosure by newspapers. In June 1990, for example, a Florida legislative committee declined to act further on a bill that "would have required . . . newspaper editorials be signed and that members of newspaper editorial boards file personal financial disclosures with the state." Financial Disclosure, Signed Editorial Bill Killed by House, NEwS MEDIA \& L., Summer 1990, at 40, 40. Such a measure likely would have violated First Amendment precedent barring government interference with editorial content. See supra notes $233-40$ and accompanying text. 
The chief historical reference point in support of this argument is the age of muckraking journalism, ${ }^{253}$ which flowered in the late nineteenth and early twentieth centuries. ${ }^{254}$ In articles written primarily for national magazines and journals, the muckrakers targeted political and industrial abuses that were ripe for reform. ${ }^{255}$ Relying considerably on facts and descriptions of inhumane conditions in their accounts, the muckrakers often took the next step beyond the limitations of objectivity. Robert Miraldi has observed that "[w] $[$ hen the facts the muckrakers collected angered them, they went beyond observation and description to advocacy for Progressive reform." 256 These activist journalists thus imported their personal values and their senses of social justice into their reporting. Ultimately, muckrakers such as Ida Tarbell, who exposed the abuses of Standard Oil, and Upton Sinclair, who chronicled exploitation in the meatpacking industry, may have induced more societal reform than any other group of reporters in the twentieth century. ${ }^{257}$

The muckraking era illustrates the virtues of allowing individual journalists the opportunity to infuse strong personal convictions into stories, buttressed by facts and empirical evidence. It offers grounds for rejecting the traditional dichotomy between partisan journalism and objective journalism. The muckrakers did not engage in the deliberate political distortions common in the early partisan press. Rather, many muckrakers actually drew on the rituals of objectivity in their efforts to research facts thoroughly and to integrate opposing points of view. ${ }^{258}$ Their departure from

253 Historian Harry H. Stein has offered this helpful characterization of muckraking: "A muckraking work exposes a hidden situation, depicts the situation prescriptively, locates an agent of control, indicates preferred action, incites audience response and maintains authorial autonomy." Harry $\mathrm{H}$. Stein, American Muckraking of Technology Since 1900, 67 JouRNALISM Q. 401, 401-02 (1990).

${ }^{254}$ See J. Herbert Altschull, From Milton To MCLuhan: ThE IDEAS BeHIND AMERICAN JOURNALISM 271-76 (1990) (describing the development of muckraking in American journalism).

255 See id. Not all of the muckrakers were driven by a reform-minded spirit. Some magazine publishers saw muckraking as a vehicle to enhance circulation and therefore actively recruited prominent journalists and writers to undertake muckraking projects. See RICHARD HOFSTADTER, THE AGE OF REFORM 192-94 (1955).

256 MIRALDI, supra note 5, at 49.

257 See id. at 5 ("By the time the muckrakers had finished their decade or so of writing, they had helped create, for better or worse, a new regulatory state and an enlarged centralized government, and they had permanently added a new weapon to the journalist's story arsenal: the muckraking exposé."); $f f$. HOFSTADTER, supra note 255, at 197 (explaining that the muckrakers inspired legislative reforms to the extent possible within the confines of existing economic structures).

${ }^{258}$ See MRALDI, supra note 5, at $\mathbf{3 2 - 3 6}$ (describing the efforts of individual 
objectivity manifested itself in their readiness to assign blame and to advocate explicitly for reform in the stories they produced. ${ }^{259}$ Based on this historical paradigm, Miraldi argues convincingly for a work ideal that merges the virtues of muckraking and objectivity. ${ }^{260}$

The conventions of modern journalism, however, operate to discourage this species of muckraking. ${ }^{261}$ Whereas muckraking often attacked establishment interests such as government and business, ${ }^{262}$ objectivity and its accompanying notions of detachment and nonparticipation may be hostile to the media's perceived overriding institutional function: its "checking value." ${ }^{263}$ This function refers to the role played by the press in "checking the abuse of power by public officials. ${ }^{n 264}$ The reign of objectivity has left the press susceptible to manipulation by government officials, ${ }^{265}$ undermining its ability to act as the "Fourth Estate"266 charged with checking the three branches of government. ${ }^{267}$

muckrakers to document their allegations and provide more fact and less opinion). 259 See id. at 36 (noting that muckrakers were "clearly trying to name names and point blame").

260 See id. at 157-60 (advocating a blend of objectivity and subjectivity in news stories).

${ }^{261}$ See id. at 6-7 (noting that most modern journalists are objective observers, adverse to asserting a position). In this regard, it should be noted that one possible cause for the decline of muckraking in the early twentieth century was the growing influence of advertisers, who provided an increasingly important share of newspaper revenue. Hofstadter notes that "[a]dvertisers did not hesitate to withdraw orders for space when their own interests or related interests were touched upon." HOFSTADTER, supra note $\mathbf{2 5 5}$, at 195 . The possible role of advertising in the demise of muckraking provides further support for the theory that objective journalism evolved as a means of satisfying the content preferences of advertisers. See supra note 126 and accompanying text.

262 See Stein, supra note 253, at 404-05 (discussing verbal attacks against large corporations and automobile manufacturers initiated by noted muckrakers).

265 See Vincent Blasi, The Checking Value in First Amendment Theory, 1977 AM. B. FOUND. RES. J. 521 (1977).

264 Id. at 527.

265 See HERTSGAARD, supra note 111, at 68-64. Hertsgaard, a media critic, argues that objectivity prevented most journalists from presenting critical coverage of the Reagan Administration, enabling White House handlers to co-opt the media as an arm of its public relations office: "In accordance with their avoidance of partisanship, many journalists seemed to regard strenuous challenging of the government as an improper violation of the rules of objectivity." Id. at 65.

${ }_{266}$ See Potter Stewart, "Or of the Press," 26 Hastings L.J. 631, 634 (1975) (suggesting that the role of the press as an adversary to the three branches of government was intended by the framers of the First Amendment).

${ }^{267}$ As an institution, the press remains extraordinarily reactive. This passivity has been borne out by the media's failure to report earlier such stories as the Iran-Contra 
The tyranny of the McCarthy era, a period when America most needed the press to fulfill its adversarial role, laid bare the stark inadequacy of objectivity. McCarthy was able to exploit objectivity's reliance on official sources and its nonconfrontational format to saturate the media with unfounded charges about the pervasive presence of Communists in the highest echelons of American government. ${ }^{268}$ The media generally reported McCarthy's claims without substantiation, ${ }^{269}$ leading to the destruction of many reputations. It was not until broadcast journalist Edward $\mathbf{R}$. Murrow crossed the barriers of objectivity that the momentum of the McCarthy hysteria abated. ${ }^{270}$ Murrow's famous See It Now broadcast, which exposed McCarthy's tactic of perpetrating groundless allegations and outright falsehoods, placed him in the tradition of the muckrakers. ${ }^{271}$ As one scholar suggested, the McCarthy era

affair, the savings and loan scandal, and the epidemic of AIDS. It reflects "the notion that a thing is not newsworthy until it becomes an event; that is, until something happens." McDonald, supra note 98, at 73 (stating further that this attitude represents "[ $t]$ he most pernicious journalistic convention" of objectivity). Modern newspapers seem reluctant to generate news through extensive and aggressive coverage of a neglected issue until an official source validates the issue. Newspapers such as the Washington Post have proven uncomfortable with the idea of shaping events in a more meaningful fashion. In the aftermath of Watergate, the Post and other papers consciously pulled back for fear of becoming "'too much an actor in the drama that was being played out." ARONSON, supra note 17, at 297 (quoting Katherine Graham, Chairperson of the Board of the Washington Post); see supra note 43 and accompanying text. Former Post executive editor Ben Bradlee has acknowledged that the paper toned down its stance in the wake of Watergate: "The criticism was that we were going on too much, and trying to make a Watergate out of everything. And I think we were sensitive to that criticism much more than we should have been, and that we did ease off." LEE \& SOLOMON, supra note 122, at 20 (quoting Ben Bradlee).

268 See ARONSON, supra note 17, at $69-72$ (noting that the objectivity of the American press prevented the exposure of "McCarthy's lies").

269 See Abramson, supra note 107, at 255 (noting that the concept of objective reporting was distorted to include stories blindly reciting McCarthy's claims).

270 See Carl HaUsman, CRISIS OF Conscience 155-56 (1992).

271 Murrow's closing words on the broadcast remain an eloquent and powerful example of journalism that filled a "leadership vacuum":

We will not walk in fear, one of another. We will not be driven by fear into an age of unreason, if we dig deep in our history and our doctrine; and remember that we are not descended from fearful men. Not from men who feared to write, to speak, to associate, and to defend causes that were for the moment unpopular.

This is no time for men who oppose Senator McCarthy's methods to keep silent-or for those who approve. We can deny our heritage and our history but we cannot escape responsibility for the result. There is no way for a citizen of a republic to abdicate his responsibility .... 
illustrates the importance of allowing an individual journalist the freedom to point to an abuse of power and state simply: "This is wrong." 272

The issues that call for a reporter to articulate "preferred action"273 in a story replete with in-depth reporting and analysis need not be as morally charged as those posed by McCarthyism. A wide range of subjects, from environmental threats to inadequate education funding to economic stagnation, may benefit from such an approach. Both the era of muckraking journalism and the example of Edward R. Murrow showed that an individual reporter, armed with the facts and a strong sense of social justice, can effect important political and societal changes. This kind of prescriptive journalism can coexist alongside straightforward factual news accounts, enriching the marketplace of ideas in journalism.

\section{Diversity and Values in the News Pages}

A policy of according individual journalists greater autonomy in their work, in conjunction with less restrictive standards on outside activity, could also enhance the content of newspapers by attracting a greater diversity of individuals with different backgrounds and values to the profession. Objectivity has inhibited political and sociological diversity in the profession insofar as it has "narrowed the range of journalists and put muckraking on the fringes of responsibility. ${ }^{.774}$ Under the reign of objectivity, moreover, studies of the press corps have found that most prominent national journalists are white, male elites. ${ }^{275}$

The actions of the Junior Senator from Wisconsin have caused alarm and dismay amongst our allies abroad and given considerable comfort to our enemies. And whose fault is that? Not really his. He didn't create this situation of fear, he merely exploited it; and rather successfully.

Cassius was right. "The fault, dear Brutus, is not in our stars, but in ourselves."

See It Now (CBS television broadcast, Mar. 9, 1954), quoted in A.M. SPERBER, MURRow: HiS LIFE AND TIMES 438-39 (1986).

272 See HAUSMAN, supra note 270 , at 155-56.

273 See Stein, supra note 253, at 402 (listing "preferred action" as one of the six elements of a muckraking report).

${ }^{274}$ MIRALDI, supra note 5, at 61 . For an explanation of muckraking, see supra notes 253-60 and accompanying text.

275 See, e.g., ARONSON, supra note 17, at 303 (noting that most of the four thousand accredited correspondents in the nation's capital are white males with college degrees); SOLEY, supra note 99 , at $21-22$ (citing a 1986 study which indicated that $95 \%$ of the 238 journalists interviewed during 1979 and 1980 were white and 79\% were male). 
The implications of this homogeneity are clear, for the composition of the media cannot be divorced from its content. The preponderance of male establishment sources in news accounts ${ }^{276}$ suggests that reporters tend to look to individuals with similar backgrounds as sources. As one commentator has noted, "[g]iven the demographic characteristics of elite reporters, it is not surprising that they use white, male elite members as their primary sources. ${ }^{277}$ The limited spectrum of political perspectives among journalists limits the dissemination of valuable political ideas and viewpoints, ${ }^{278}$ which instead may be casually dismissed as "radical" or "out of the mainstream."

Sociologist Herbert Gans, who studied journalists at prominent media organizations in the 1970 s, found that individuals who have difficulty suppressing their personal values rarely seek employment as reporters and editors. ${ }^{279}$ Moreover, "the national media, and journalism generally, appear to recruit people who do not hold

One New York Times correspondent offered this description of the homogenization of the press corps:

"This used to be a business that attracted a lot of nonconformists, oddballs and unusual characters, in terms of interest, background and appearance. A lot of that seems to have been leached out of the business somehow. I look around the New York Times newsroom [now], it looks like a law firm." HERTSGAARD, supra note 111, at $\mathbf{8 0}$ (quoting New York Times reporter R.W. "Johnny" Apple). The news business appears to be generally lacking in racial and sexual diversity. Minorities currently comprise less than $10 \%$ of newsroom personnel compared to about $20 \%$ of the population at large. See Katherine Corcoran, Reaching for Diversity, WASH. JOURNALISM REV., July/Aug. 1992, at 38, 40. Women also remain sharply underrepresented on news staffs. Recent studies of 10 leading newspapers found that only $27 \%$ of their front-page by-lines belonged to women. See LEE \& SOLOMON, supra note 122, at 229, 393 (citing studies conducted by the University of Missouri and the Communications Consortium). The exclusion of women extends to the editorial and commentary pages as well. A study of New York Times op-ed pages found that women accounted for only $13 \%$ of 909 opinion articles written by outside contributors during the first half of 1989. See id. at 230, 393 (citing Mother Jones).

276 See supra note 106 and accompanying text.

277 Soley, supra note 99 , at 22 . For example, a 1989 study found that women accounted for only 11\% of individuals who were quoted in front-page stories of 10 leading newspapers. See LEE \& SOLOMON, supra note 122, at 230, 393 (citing study conducted by the Communications Consortium).

278 See, e.g., The Case of the Closet Socialist, Colum. Journalism Rev., Mar./Apr. 1989, at 16, 17 (contending that "there is strong historical evidence that other perspectives-specifically, socialist perspectives-can contribute not only to robust journalism but also to a country's self-knowledge").

279 See GANS, supra note 115 , at 184 (noting that the new media seems to "attract people who keep their values to themselves"). 
strong personal values in the first place. ${ }^{n 280}$ In this fashion, journalism may have excluded a significant body of talent from the profession. Newspaper ethics that manifest greater tolerance for individual activism could attract individuals with diverse values and demographics back to journalism and thereby enliven the composition of the press pool.

Broadening the political and sociological spectrum of reporters and editors may concomitantly expand the types of stories that get covered and the way those stories get reported. ${ }^{281}$ The very process of story selection and placement can become a form of activism in today's homogenous news market. ${ }^{282}$ Reporters with varying perspectives may be more likely to seek out nonestablishment or unconventional sources. One recent study found that lesser reliance on official sources is characteristic of "enterprise" journalism, a category which encompasses investigative reports, multi-part expositions and other interpretive accounts. ${ }^{283}$ The

$280 \mathrm{Id}$.

281 In 1989, A. Kent MacDougall, a former reporter for the Wall Street Journal and the Los Angeles Times, created a furor when he claimed that he had been a "closet socialist" working to infuse radical values into those mainstream papers. Although MacDougall acknowledged that most of his reporting fell within the conventions of modern professional standards, he nonetheless exposed Journal readers to a set of radical values by writing "front-page stories on radical historians, radical economists, and leftist journalist I.F. Stone." A. Kent MacDougall, Memoirs of a Radical in the Mainstream Press, ColUM.JOURNALISM REV., Mar./Apr. 1989, at 36, 36. MacDougall's editors, meanwhile, said that while MacDougall generally met the standards of objectivity, they were well aware of his personal ideology and "looked at his stories accordingly" in order to remove any "hints of bias." David Shaw, $A$ "Closet Socialist" Stirs Furor Over News Stories, L.A. TIMES, Jan. 31, 1989, § 1, at 1, 16 (quoting Los Angeles Times editor John Lawrence).

More generally, the presence of more women in the newsroom, for example, may result in more meaningful coverage of issues that otherwise might remain underreported. At The New York Times, for example, "[w] hereas some men on the national staff tended to pass over or downplay such subjects as birth control or toxic shock, the women would say, "Wait a minute-this is a hell of story." NAN ROBERTSON, THE GIRLS IN THE BALCONY: WOMEN, MEN, AND THE NEW YORK TIMES 237-38 (1992) (paraphrasing comments of New York Times assistant managing editor Dave Jones).

282 See, e.g., Doron P. Levin, Black Jourmalists Tell of Facing New Job Pressures, N. Y. Times, Aug. 22, 1992, at A5 (reporting journalist Garry Pierre-Pierre's belief that "his choice of story subjects by itself constituted activism").

283 See Kathleen A. Hansen, Source Diversity and Newspaper Enterprise Journalism, 68 JoURNALISM Q. 474, 476 (1991). The study, which analyzed 60 enterprise stories published in large metropolitan dailies, found that government sources accounted for about $40 \%$ of the content of those stories. This finding contrasted with previous studies of front-page newspaper stories that found government sources comprised between 60 and $80 \%$ of content. See id. at 477 . Enterprise reports more often included the views of both ordinary, unaffiliated individuals and representatives of 
study concluded that "[i]f daily news content can reflect some of the source diversity characteristics displayed in enterprise reporting projects, it may be possible to better meet the basic expectations for non-government-official-dominated media., ${ }^{284}$ Source diversity thus implicates not only the values associated with pluralism, but also the checking function of the press insofar as it enables journalists to break free of excessive reliance on the government for information. 285

\section{CoNCLUSION}

This Comment has urged that newspapers abandon prevailing ethical standards that subordinate the free speech interests of individual journalists to concerns about "appearances." All too often, the implementation of these standards have unethical consequences: newspapers have relied upon attenuated claims concerning objectivity and the appearance of neutrality to justify interference with the private lives of reporters even where media content is not implicated. A more honest set of ethical norms would recognize that absolute neutrality is illusory because all reporters have experiences and affiliations that shape their development as both press professionals and human beings. All journalists must have at least some political or social impulses and passions that surface in the course of their day-to-day lives. As the incidents described in this Comment suggest, the individuals who comprise the media can also be mothers concerned with the quality of their children's education, churchgoers committed to devout religious beliefs, feminists dedicated to the preservation and expansion of women's rights, community members preoccupied with the quality of their local political representation, and, more generally, citizens concerned about the health of their society.

various nongovernmental interests such as labor and education. "This would indicate that the enterprise projects may be doing a better job of meeting the basic expectations of a pluralistic medium because they are making an effort to broaden the scope of sources included in projects." Id. at 478.

284 Id. at $481-82$.

285 To the extent that it produces news stories that speak to the concerns of a broader range of groups in society, such diversity can also have economic rewards. With newspaper circulation levels currently mired in stagnation, and with minorities comprising an increasingly large percentage of the population, industry executives are beginning to appreciate the need for diversity as a strategy for reaching new readers. See Corcoran, supra note 275, at 40. 
Newspapers should not aim to convey the false impression that these impulses do not exist by barring participation in issue demonstrations or community affairs. Rather, newspapers should encourage journalism that candidly acknowledges biases, identifies more readily with the community, and thereby connects more meaningfully to readers. A movement toward allowing newsroom professionals the freedom to become more integrated into the communities they cover, both as private citizens and as journalists, represents an important part of that process. 
